\title{
Minimally Sufficient Deterrence
}

\begin{abstract}
A B S T RACT
Dangers exist in both maximalist approaches to deterrence and minimalist ones. A minimal sufficiency strategy aims to avert these dangers. The objectives are to convince people that the webs of relationships within which they live mean that lawbreaking will ultimately lead to desistance and remorse and to persuading offenders that predatory crime is simply wrong. Alternative support and control strategies should be attempted until desistance finally occurs. Communities can be helped to understand that this is how minimally sufficient deterrence works. By relying on layered strategies, this approach takes deterrence theory onto the terrain of complexity theory. It integrates approaches based on social support and recovery capital, dynamic concentration of deterrence, restorative justice, shame and pride management, responsive regulation, responsivity, indirect reciprocity, and incapacitation. Deterrence fails when it rejects complexity in favor of simple theories such as rational choice.
\end{abstract}

Some criminologists are inclined to question why any role should be given to deterrent crime prevention strategies. The evidence for the power of deterrence in reducing crime is thin, after all (Nagin 2013; Chalfin and McCrary 2017; Tonry 2018). There are three reasons why deterrence should have a role. One is that a good meta-strategy for crime control achieves strength through the convergence of weaknesses: deterrence can help to motivate crime control strategies that are more effective than

Electronically published February 27, 2018

John Braithwaite is Distinguished Professor and founder of the Regulatory Institutions Network, Australian National University.

(C) 2018 by The University of Chicago. All rights reserved. 0192-3234/2018/0047-0006\$10.00 
deterrence. Second, deterrence is a weak strategy that can be tried after various somewhat less weak strategies have failed, strengthening the efficacy of a complex approach tied together as a bricolage of strategies. Third, when deterrence of a specific offender fails, it might slightly strengthen general deterrence of other offenders. Sometimes punishment or the threat of punishment provokes defiant reactions that can make crime more likely, not less. For most values of relevant variables, defiance effects exceed deterrence, but there are some contexts in which specific deterrence exceeds defiance. For these reasons, I reject deterrence minimalism in favor of minimally sufficient deterrence.

Deterrence maximalism has even less appeal. Zero tolerance and other political slogans of deterrence maximalism are common, doubtless helpful in election campaigns, but are dismissed by scholars who understand the evidence. Deterrence is not the main game of crime control. Even so, it is reckless to fail to develop a coherent view of the constructive role deterrence must have in crime prevention. A transdisciplinary scientific consensus about the limits of deterrence is behind growing support for "less prison, more police, less crime" as a prescription grounded in preventive capacities of evidence-based policing (Durlauf and Nagin 2011; Travis, Western, and Redburn 2014). In light of the data on the limited effectiveness of deterrence and the cost of building prisons, it is imperative to advocate massive disinvestment from putting people in them.

Likewise, it is easy to dismiss maximizing the shame aimed at offenders, even though shame has a role in minimally sufficient deterrence. Some criminologists conclude that there is strong evidence that shame has power in crime control (Braithwaite 1989), but they do not advocate maximizing the shame directed at offenders. Persuasive evidence shows that this strategy leads to stigmatization, which makes crime worse (Ahmed et al. 2001, pp. 3-72).

Moreover, we know that healthy pride management may be as important as, or more important than, healthy shame management (Maruna 2001; Ahmed and Braithwaite 2011; Best 2017). Intentionally directing unhealthy shame at offenders may crowd healthy pride out. There is unhealthy shame that increases crime and healthy shame acknowledgment that helps prevent crime and repair harms. Likewise, there is unhealthy pride that fosters crime by vaunting superiority over others and humble pride in doing things well with others that is vital to crime prevention via pride in the identity of being a law-abiding citizen who cares about the suffering of others (Ahmed and Braithwaite 2011). Deterrence does 
best when it does not crowd out healthy shame acknowledgment and healthy pride in a law-abiding self. A virtue of minimally sufficient deterrence is that it minimizes that stigmatic crowding out that is inherent in deterrence maximalism.

Progressives who seek to minimize the quantum of fear or shame that criminal justice system processes invoke are also a danger. It is dangerous, for example, to conceive restorative justice as an abolitionist prescription that eliminates the need for punishment and deterrence. Restorative justice is a strategy that gives an opportunity to all the stakeholders in a crime to participate in a process that discusses who has been harmed or has needs, and what might be done to repair those harms and meet their needs (Zehr 2015). Because crime hurts, justice should heal. Restorative justice conceived as eliminating the need for deterrence is denial of the reality that if we gave criminal offenders the choice of either restorative justice processes in which they agree to repair the harm they caused or doing nothing and forgetting about it, most would opt to forget it. Offenders agree to participate in restorative justice because the alternative has deterrent elements. We see from this that a useful role for deterrence is that it motivates engagement with something that is more effective than deterrence: restorative justice and the rehabilitative and preventive measures for which restorative justice is a delivery vehicle. Indeed, wise integration of restorative justice, rehabilitation, and deterrence allows restorative justice to strengthen the preventive power of deterrence, in addition to allowing deterrence to strengthen restorative justice and rehabilitation. The ambition is to identify a good meta-strategy for crime control that achieves strengths from the convergence of weaknesses: in this example, weaknesses of both deterrence and restorative justice. Some restorative justice advocates are minimalists about shame (e.g., Maxwell and Morris 2002). A society in which rape and violence are minimally shameful will be a society with high rates of rape and violence (Braithwaite 1989, 1995). Hence, it is imperative to diagnose what a minimal sufficiency of the right kind of shame might mean.

Minimum deterrence and minimum shame are inferior to minimal sufficiency: just enough of the right kinds of deterrence and shame is needed. Deterrence and shaming are more effective when combined with a dynamic theory of social support. Communicating the shamefulness of predatory crime is more effective when combined with reintegration of offenders - reintegrative shaming. As with deterring crime, deterring warfare works better when armed fighters are simultaneously shown the 
costs of killing and shown a supportive peace dividend that benefits them, their family, and their community (Toft 2010; Braithwaite and D'Costa 2018, chap. 3). This is why there is strong evidence that armed peacekeepers prevent war when they do multidimensional peace building that supportively delivers peace dividends (Doyle and Sambanis 2006; Fortna 2008; Call 2012). It is also why simplistic strategies of deterrence maximalism by threatening foes with accelerating military investment can cause more war.

Criminological theory needs something better than cynicism driven by piling up empirical studies about limits of deterrence. Few citizens think deterrence has no role to play in the prevention of rape, theft, or corporate crime. In failing to develop a theory of deterrence that takes fear and shame seriously in social control, criminologists have handed the deterrence debate to maximalists.

This is sad because deterrence maximalists justify a greatly increased level of suffering for incarcerated people and their families. Maximalism increases crime by skewing government budgets to prisons that worsen the criminality of those sentenced to them (Nagin, Cullen, and Jonson 2009). Yet maximalists make more sense to the community than criminologists who say only that punishment deters little. One way of conceiving the imperative to take deterrence seriously, even if minimally, is that deterrence underwrites the greatest historical accomplishment of the justice system. Eisner (2003, p. 126) revealed sharply falling homicide rates between the sixteenth and seventeenth centuries across Europe, the period when some European states institutionalized courts to "discipline" violence. The capability of the courts in the eyes of citizens to deter violence was one reason they abandoned the private deterrence of blood feuds, thereby greatly reducing homicides (Pinker 2011).

A minimal sufficiency strategy of punishment can increase the power of deterrence theory in crime prevention substantially if its empirical claims are more strongly verified by future research and if it can win the political debate against maximalists. It can increase the power of deterrence with a policy that experiences release of the majority of prisoners even in the societies with the lowest imprisonment rates. Minimal sufficiency's claims are consistent with the rather limited existing evidence.

My aim here is to develop ideas toward a theory of minimally sufficient deterrence and to reflect on that existing evidence. To do that, I discuss seven interwoven principles of a crime prevention meta-strategy for minimally sufficient deterrence: 
1. Escalate enforcement. Display intent to progressively escalate a responsive enforcement pyramid that involves progressive escalation of sanctions for wrongdoing and support for social responsibility.

2. Inexorability. Pursue inexorable consistency of detection of predatory crime. Communicate inexorable community commitment to stick with social support for those struggling with problems of lawbreaking until the problems are fixed.

3. Escalate social support. With repeated offending, increase social support. Even when there is escalation to a last resort of severe incapacitation, escalate social support further. Keep escalating social support until desistance is consolidated.

4. Sharpen the Sword of Damocles. Cultivate the perception that "Trouble hangs inexorably over my head; they want to support me to avert it."

5. Dynamic concentration of deterrence. Focus deterrence on lines that should never be crossed after an announcement date. Then progressively lift that line, raising our expectations of socially responsible citizens.

6. Community engagement. Engage the community with offenders in widening restorative conversations that educate in the shamefulness of criminal predation for the many who participate in the conversations. Avert stigmatization.

7. Modesty. Settle for the modest general deterrence delivered by this shamefulness and a minimal number of cases that escalate toward the peak of the enforcement pyramid.

In this essay, I first explain the idea of the responsive regulatory pyramid. It provides a scaffolding into which to insert all seven principles. Readers versed in the literature of restorative justice and responsive regulation may find much of the pyramid discussion familiar; I elaborate it for the benefit of others. I then explain the importance of inexorable response, then the theory of dynamic deterrence and defiance, and then how to constitute the shamefulness of the curriculum of crimes. I conclude with minimally sufficient general deterrence.

\section{The Regulatory Pyramid}

The regulatory pyramid is a meta-strategy of regulation, a strategy for how to sequence strategies (Braithwaite 2008). It is relevant to regulat- 
ing crime by organizations or individuals. Figure 1 is an example of a regulatory pyramid elaborated in the next section. The presumptive strategy (a presumption that can be overruled) is to start at the base of the pyramid and escalate slowly. This is a strategy for keeping the Sword of Damocles sharp by making it rare to reach the pointy end of the pyramid. I discuss the rationale for keeping the Sword of Damocles sharp

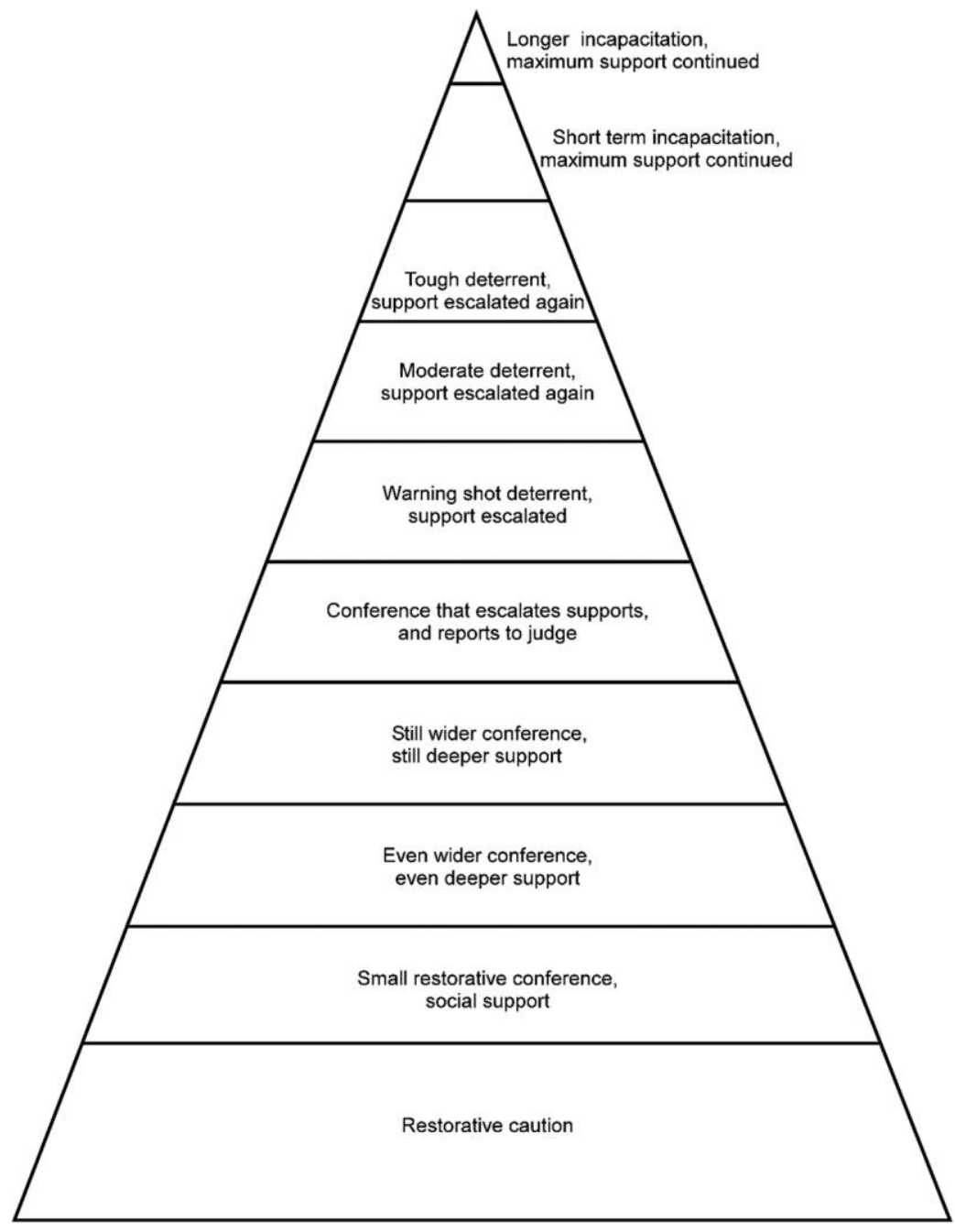

FIG. 1.- Responsive pyramid model incorporating minimally sufficient deterrence 
in a later section. Consistent with the limited evidence on what works with corporate crime enforcement (Schell-Busey et al. 2016), this is a strategy that provides a wide mix of regulatory options before measures are reached that risk blunting the Sword of Damocles. At the bottom of the pyramid are restorative strategies that provide support to offenders and victims, meet needs, and repair harms.

Responsive regulatory theory says that we should first look to the strengths of a lawbreaker and then seek to expand them. Mental health researchers led in showing that training in building on strengths improves quality of life and vocational and educational outcomes (Stanard 1999). When those outcomes are improved, recent econometric findings show more clearly than in the past that unemployment can be averted, that this reduces crime, and that wages for the poor can be increased, reducing crime by increasing the attractiveness of legitimate work compared to illegitimate work (Chalfin and McCrary 2017, pp. 33-35). This path to crime reduction is resource intensive, though less so than a massive prison system, and it is a benefit to the economy in contrast to the economic deadweight of many large prisons. The idea is to absorb weaknesses by expanding strengths. Put another way, regulators should not rush to law enforcement solutions before considering a range of restorative approaches that can be delivery vehicles for capacity building. As some regulated actors see their strengths expand to levels not previously conceived to be possible, regulators celebrate their innovation, publicize it, and support its extension. With corporate enforcement, research grants and prizes for rolling out new approaches that take internal compliance systems up through new ceilings for that industry offer an example. An example involving young black men in Minneapolis is use of celebration circles in which victims join with the offender's loved ones to celebrate the way an offender has repaired the harm, righted the wrong, and turned his life around (Braithwaite 2002, p. 103).

As we move up the pyramid through a first to a second to a third restorative conference, conference participants are likely to decide to escalate to increasingly punitive interventions. The policy idea is to persuade participants that they should also keep escalating to new ideas and resources for providing support for the offender. The philosophy of restorative justice is to empower stakeholders to take advice from experts but then to make their own decisions contextually attuned to the circumstances of their offender. This includes knowledge of the programs the community of care can persuade the offender to complete and the 
needs of his or her victim and other stakeholders in their conference. A problem with this is that it does lead to a bricolage of community responses rather than one that maps mechanically from "what works" criminology. This is a complex relational and community empowerment process in which the problem rather than a stigmatized individual is at the center of the circle. The content of the pyramid is not prescriptive. The use of terms such as "escalated support," between "wide" and "wider" support, and "escalated deterrence" without specifying escalation "to what specific measures" is intentional.

With complex phenomena, it is best not to follow the most evidencebased strategy, but the best meta-strategy. The research question of which strategy works best is trivial compared to the question of which meta-strategy works best. Rarely will the first strategy attempted work in a complex context that differs from the conditions of a controlled evaluation trial. A good meta-strategy will inform stakeholders of results from the "what works" literature and will presumptively try the most strongly supported strategy first and then the second most strongly supported strategy (after the first strategy fails). That presumption can be overridden in light of particular circumstances. Clinicians, by analogy, try one therapy after another for a patient, informed by their knowledge of the outcomes of randomized controlled trials and also their knowledge of particular cases, including what other medications patients are taking, their capabilities for surviving the side effects of a therapy, how strong their hearts are, and much more. As in restorative practice, clinicians can also decide what to recommend in order to catalyze community controls that will prevent spread of a contagion. In neither case does best practice involve a narrow focus on an individuated view of what works.

More detailed discussions of how to go about the process of deciding when and how to escalate up a responsive regulatory pyramid, and how to mobilize networked escalation as opposed to simple state escalation, can be found in Braithwaite, Makkai, and Braithwaite (2007) and Braithwaite (2008, 2011). Intervention in complex phenomena like criminal careers should follow a trajectory that first assumes answers are knowable and known and therefore apply evidence-based strategies from normal science (Braithwaite and D'Costa 2018, chap. 12). When that fails, assume the challenge is knowable but unknown (and work to acquire at least some contextual qualitative understanding of the knowable). Then if that repeatedly fails, assume one is dealing with a complex or chaotic phenomenon that is unknowable. In that situation of unknowability, do not surren- 
der to analysis paralysis; keep probing with new forms of social support that come out of restorative conversations until a resonant response begins to produce positive change.

At the base of the responsive pyramid of sanctions are the most restorative, dialogue-based approaches we can craft for securing compliance with a just law. Of course, one reason for an approach that is deliberatively responsive to complexity is that a particular law, or its interpretation, may be of doubtful justice, in which case we can expect dialogue mainly to be about the justice of the law. If excessive force was used during arrest or if racism was in play, we can expect dialogue about whether it is the defendant or the police who have committed the greater crime. This is a good thing from a civic republican perspective, which provides a normative motivation for the theory (Braithwaite and Pettit 1990). As we move up the sanctions pyramid, increasingly demanding interventions are involved. The idea of the pyramid is that our presumption should always be to start at the base. Then escalate to somewhat punitive approaches only reluctantly and only when dialogue fails. Then escalate to even more punitive approaches only when more modest sanctions fail.

Strategic use of the pyramid requires the regulator to resist categorizing problems into minor matters that should be dealt with at the base of the pyramid, more serious ones that should be in the middle, and egregious crimes at the pyramid's peak. The presumptive preference, even for serious crimes, is to try dialogue first, overriding that presumption only if there are compelling reasons for doing so. There will be such reasons in exceptional cases: a violent first offender who vows to keep pursuing the victim to kill her may have to be locked up; a person who has never offended but attempts to blow herself up in a subway may be killed by police who get a clear shot. The 2005 incident in which British police shot an innocent Brazilian man in a subway who was suspected of terrorist intent illustrates the justification for the responsive regulatory imperative always to consider, however quickly, the viability of interventions at lower levels of the pyramid.

As we move up the pyramid in response to a failure to elicit restorative reform and repair, in most cases we eventually reach the point at which reform and repair are forthcoming, even if it is many years later. Whenever that point is reached, responsive regulation means that escalation is reversed; the regulator de-escalates down. The pyramid is firm yet forgiving in its demands for compliance. Reform must be rewarded just as recalcitrant refusal to reform is ultimately punished. 
A dramatic transformation of criminal law jurisprudence will be necessary if evidence continues to mount supportive of responsive regulatory theory and we as a society are to reap the benefits of less crime (Braithwaite and Pettit 1990). The imperative to de-escalate deterrence responsively when an offender rehabilitates means that every year a reformed person remains in prison is needless suffering. It is a frittering away of society's scarce crime control resources.

If the empirical claims of responsive regulatory theory are right, this is also a missed opportunity to reduce crime by putting rewards for rejecting a life of crime alongside sanctions for embracing crime. In practical terms, what is needed when social support succeeds in helping a prisoner serving a long sentence turn his or her back on a life of crime is a return to the sentencing court for a hearing about the possibility of early release. The sentencing judge in such hearings should be obliged to take into account the views of victims who are willing to listen to the opinions of parole professionals, the offender, and the offender's family. From a responsive regulatory perspective, a criminal law that keeps people in prison until they have paid the proportionate penalty for their wrongdoing is a profound folly. It is an indefensible policy in terms of a dynamic theory of deterrence. It can make deterrence sense only under a passive deterrence theory, especially a maximalist one, the passive theory that minimally sufficient deterrence seeks to render obsolete.

The deterrent superiority of the active deterrence of the pyramid, as opposed to the passive deterrence of a fixed scale of consistently imposed penalties, is elaborated in Braithwaite (2002, pp. 73-136). Consistently proportionate punishment is justified by proponents of a just deserts theory of equal punishment for equal wrongs. Equal punishment for equal wrongs, however, is a danger to justice. It privileges punitive equality for offenders, while riding roughshod over the justice claims of future victims of crime who suffer because of an inferior crime prevention policy, of present victims who may not want equal justice for equal wrongs to apply in their case (e.g., who may prefer more compensation and less imprisonment), and of offenders' family members who suffer to variable degrees as a result of a breadwinner being in prison (Braithwaite 2002, 2003).

In any event, what kind of equality is expressed by a logic of equal punishment for equal wrongs when some offenders are lucky enough not to be raped or bashed in prison and others do suffer these horrors; when some are trapped in prison-induced contagions of drug addiction and others are not; when some acquire HIV, hepatitis, or tuberculosis in 
prison systems that are the best-known incubators of these contagions, and some do not? This is not to disagree that maximum sentences should be set on the basis of seriousness but to say that the right sentence is the minimally sufficient one.

Responsive regulation has had modest influence as a policy idea in the domains of business regulation and corporate crime enforcement because it formulated a way to reconcile the clear empirical evidence that sometimes sanctions work and sometimes they backfire-and likewise with social support. The evidence of this is just as clear with common crime; yet responsive regulation has had almost no influence on policing policies. This would not have surprised Edwin Sutherland ([1949] 1983), who 60 years ago first demonstrated propensities to tolerate forgiving approaches toward crime in the suites that are seldom evident toward crime in the streets.

Restorative justice provides stakeholders with professional advice on rehabilitation and prevention options they might choose. The community of care can then be mobilized to monitor and enforce compliance with whatever is undertaken. This is an approach informed by values that define not only a just legal order but also a caring civil society. These values are derived from the foundational republican value of freedom as nondomination (Braithwaite and Pettit 1990; Pettit 1997). Some who share these restorative values derive them from different foundations, including spiritual ones.

Ordering strategies in the pyramid is not just about putting less costly, less coercive, more respectful options lower down in order to save money and preserve freedom as nondomination. It is also that use of more dominating, less respectful forms of social control only after more dialogic forms have been tried first comes to be seen as more legitimate. When regulation is seen as more legitimate and more procedurally fair, compliance with law is more likely (Tyler 1990; Tyler and Huo 2002). Astute business regulators often set up this legitimacy explicitly (Dekker and Breakey 2016). During a restorative dialogue over an offense, the inspector will say there will be no penalty this time, but she hopes the manager understands that if she returns to find the company has slipped out of compliance again, she will have no choice but to refer it to the prosecutions unit. If and when the manager explicitly agrees that this is a reasonable approach, a future prosecution will likely be viewed as fair. Under this theory, therefore, privileging restorative justice at the base of the pyramid builds legitimacy and therefore prevents crime. 
There is also a rational choice account of why the pyramid works. System capacity crises result in pretenses of consistent law enforcement when the reality is that punishment is spread thinly, weakly (Pontell 1978; Pontell, Black, and Geis 2014). Unfortunately, this problem will be worst when lawbreaking is worst; criminal justice is a sprinkler system that fails when the fire gets hot. Hardened offenders learn that the odds of serious punishment are low for any particular infraction. Tools like tax audits that are supposed to be about deterrence can backfire by teaching tax cheats how much they can get away with (Kinsey 1986). ${ }^{1}$ The reluctance to escalate under the responsive pyramid model means that enforcement can be selective in a principled way. The display of the pyramid itself channels the rational actor down to the base of the pyramid. Noncompliance comes to be seen (accurately) as a slippery slope. In effect, the pyramid solves the system capacity problem by making punishment cheap. The pyramid says "unless you punish yourself for lawbreaking through an agreed action plan near the base of the pyramid, we will punish you more severely higher up the pyramid (and we stand ready to go as high as we have to)." So, it is cheaper for the rational actor to self-punish (as by agreeing to payouts to victims or community service). Some Asian criminal justice systems, such as that of Japan, work this way much of the time, even for serious crimes such as rape, aggravated assault, and murder that are frequently resolved through compensation and remorseful apology rather than through prison time, without such reparative leniency causing crime to spin out of control (Ahmed et al. 2001). Once the pyramid succeeds in creating a world in which most punishment is selfpunishment, there is no longer a crisis of capacity to deliver punishment when it is needed. One of the messages the pyramid provides to corporate criminals is that "if you violate repeatedly without reform, it is going to be cheap for us to hurt you (because you are going to help us hurt you)" (Ayres and Braithwaite 1992, p. 44).

Paternoster and Simpson (1996) showed the limits of passive specific deterrence on intentions to commit corporate crime. When respondents held personal moral codes, these were more important for predicting compliance than were rational calculations of sanction threats (though the lat-

\footnotetext{
${ }^{1}$ On balance, however, Mazzolini, Pagani, and Santoro (2017) found that audits increased reported income by 8 percent on average, though audits that detected no extra tax liability reduced future reported income in the short term. See also Mendoza, Wielhouwer, and Kirchler (2017).
} 
ter were important too). Appeals to business ethics (e.g., through restorative justice that exposes executives to consequences for victims of a corporate crime) therefore may be a better first strategy than sanction threats (Parker 2004). Best to succeed or fail with such ethical appeals first and then escalate to deterrence for the minority of contexts in which deterrence works better than ethical appeals. One of the psychological principles in play here is that when intrinsic motivation to comply with the law is intact, we do not want to crowd out intrinsic motivation with extrinsic threats (Ayres and Braithwaite 1992, pp. 49-50; Osterloh and Frey 2013; Frey 2017). Nine meta-analyses after responsive theory and behavioral economics picked up "crowding out" and "minimal sufficiency" from developmental psychology, there remains strong psychological evidence that crowding out does occur but also that intrinsic and extrinsic motivations both independently affect behavior (Cerasoli, Nicklin, and Ford 2014).

According to responsive regulatory theory, what we want is a legal system in which citizens learn that responsiveness is the way our legal institutions work. Once they see law as a responsive regulatory system, they know that there will be a chance to argue about unjust laws or unjust enforcement (as opposed to being forced into a lower court production line or a plea bargain). But they will also see that game playing to avoid legal obligations inexorably produces escalation. So does failure to listen to arguments about the harms their actions are doing and what redress is required. The forces of law are listening, fair, and therefore legitimate, but also ultimately are viewed as invincible.

A paradox of the pyramid is that to the extent that we can guarantee a commitment to escalate if steps are not taken to prevent the recurrence of lawbreaking, then escalation beyond the lower levels of the pyramid need rarely occur. This is the image of invincibility making self-regulation probable. Without locked-in commitment to escalation when reform fails to fix the problem, the system capacity crisis rebounds. A fundamental resource of responsive regulation is the belief of citizens in the inexorability of escalation if problems are not fixed.

Restorative justice works best with a specter of punishment threatening in the background but never threatened in the foreground. When punishment is thrust into the foreground even by implied threats, otherregarding deliberation is made difficult because the offender is pushed to deliberate in a self-regarding way - out of concern to protect him- or herself from punishment. This is not the way to engender empathy with the victim, internalization of the values of the law, and the values of restor- 
ative justice. The job of responsive regulators is to treat offenders as worthy of trust. When regulators do this, the law more often achieves its objectives (Braithwaite and Makkai 1994; Gangl, Hofmann, and Kirchler 2015; Haas et al. 2015). The ideal is to enculturate trust (in the foreground) while institutionalizing distrust (in the background) through deterrence as a last resort (Braithwaite 1998).

Testing theories about dynamic interventions layered in a pyramid is more complex than testing the effects of passive policies like heavier sentences because the effects of sequences of interventions must be tested. How can a regulatory pyramid be tested when it involves an entire suite of sequenced dialogic, then deterrent, and then incapacitative approaches? It has worked in raising an extra billion dollars in tax for each million spent on a program for multinational companies engaged in illegal profit shifting (to tax havens, e.g.; Braithwaite 2005, pp. 89-100). Evaluation in a tax compliance context requires first the creation of this whole pyramid of sequenced new policies for companies that have been paying no tax, and then observation of how much tax they pay after the new pyramid is put in place, as well as observing at what sequenced stage of the pyramid most tax payment starts to flow. The quality of information from the latter observations is instructive, yet low, because we do not know whether a compliance effect is the result of the last step up the pyramid or a combined effect of some subset of the whole sequence of escalations. A comparable evaluation challenge applies to problem-oriented policing as a meta-strategy. Randomizing some police patrols to problem-oriented policing shows that problem-oriented policing works as a meta-strategy (Braga 2002; Weisburd et al. 2010), but it gives feedback of limited quality on which initiatives addressing what problems produced the result. Even so, evaluating meta-strategies is more important work for criminology than evaluating single crime control strategies. How to think clearly about evidence in relation to dynamic theories of support and sanctions is the topic of a complementary paper (Braithwaite 2016).

\section{Inexorability of Support and Sanctions}

Inexorability has three elements:

- prioritizing increased consistency of detection above tougher punishment; 
- always taking serious crimes seriously with a continuum of restorative responses to every detected serious crime; avoiding "do nothing" responses;

- escalating the seriousness of response to a second, third, and fourth offense; sticking with the problem until it goes away.

\section{A. Prioritize Detection}

The inexorability piece of the theory builds on the evidence from the deterrence literature that perceived and actual severity of punishment are rarely good predictors of compliance with the law, while perceived and actual certainty of detection are often useful predictors (Blumstein 2011; Robinson 2011; Friesen 2012; Nagin 2013). One reason for this is that detection mobilizes not only formal punishment but also informal disapproval, which is a more powerful driver of compliance with the law (Braithwaite 1989). Theoretically, this is not just about an evolution of cooperation (Axelrod 1984), an evolution of compliance when noncompliance is visible to a punisher. The newer theoretical insight is that it is also about indirect reciprocity through fear of reputational loss even without repeated encounters with the same people (Berger 2011; Nowak 2012; Braithwaite and Hong 2015). Criminologists therefore tend to read the deterrence literature as showing that "detection deterrence" and "disapproval deterrence," both specific and general, are more powerful than deterrence by severe formal sentences. Minimally sufficient deterrence is based on this view that "detection deterrence," indirect reciprocity, and "disapproval deterrence" are indeed more powerful than deterrence by severe state punishment.

\section{B. Always Respond}

Inexorability is absent in contemporary urban justice. Enforcement swamping and system capacity overload mean that young people picked up as minor first offenders learn that they do not receive significant punishments even if they are prosecuted. This is also likely to happen with their second, third, or fourth minor offenses during their teenage years. When the system does finally decide to hit youth offenders hard because someone decides they have "had enough chances," offenders wonder "why now?" Legitimacy is obviously a casualty of this policing strategy for muddling through system capacity crises. Tough punishment seems 
to repeat offenders to have unfairly come out of the blue, when they got away with worse in the past, when they see friends get away with even worse. Because this seems arbitrary, it has shallow legitimacy in their eyes. In the next section, I consider an alternative response approach to first, second, third, fourth, and fifth offenses.

\section{Escalate Responses}

The trouble with inexorability is that it is hard to reconcile with minimal sufficiency of punishment. Punishing everyone detected seems like maximal net widening rather than minimally sufficient. The challenge of averting net widening is to craft a minimally sufficient response for a minor first offense. Police, teachers, or parents who observe children hitting each other do well to pause to insist that they stop fighting and say something nonstigmatizing like "You guys are better than that," and then walk on. This is a better way of taking violence seriously than looking the other way. It is more than "nattering" as one walks by without stopping the violence (Patterson and Bank 1989) but less than net widening, which creates some kind of recording of alleged wrongdoing.

Restorative theory can inform an inexorability that averts a perception of an arbitrary punishment lottery. The evidence is strong that restorative justice buttresses the legitimacy of the justice system (Tyler et al. 2007; Sherman 2014; Barnes et al. 2015; Miller and Hefner 2015). Prosecution is not the way to go with a first-offending child arrested for a petty offense. Nor is turning a blind eye. A restorative police caution with a degree of ritual seriousness is an option. Police can respond to a shopkeeper holding a child who has stolen something by ensuring the child returns stolen property and taking the shopkeeper's contact details, and then either taking the child home to ask parents or guardians what they intend to do or holding the child at the police station until parents arrive to take him home following a restorative caution. The restorative caution gives the child and parent space to come up with the suggestion that they will visit the shopkeeper together to apologize, perhaps even bake a cake or bring some flowers. Traditionalists see such idiosyncratic gestures of apology as strange elements to take seriously in criminal justice policy; yet that is the essence of trusting the community rather than the police with averting an offender's reaction that "nothing happened, so breaking the law is no big deal." Police tell the parents that they expect a text advising what has been done to apologize. The police say they may check 
that the shopkeeper is satisfied. In other words, most of the work of social disapproval is delegated away from the police. One reason for this as one approach to taking every crime seriously is the evidence that censure by families and closest friends is more likely to be a reintegrative form of shaming, while censure by criminal justice officials is more likely to be stigmatizing (Ahmed et al. 2001, pp. 157-76).

So, what to do with the teenager's second minor offense? The minimally sufficient deterrence suggestion is a restorative justice conference that the victim is invited to attend. The child's loved ones would be expected to sit in the circle for a serious family ritual of parents, grandparents, siblings, perhaps aunts, uncles, and a sports coach or a teacher trusted and nominated by the child. Communicating this expectation is important because a concern is to ensure that overburdened mothers do not shoulder all the burdens of social support. Wider circles of participation also enhance the effectiveness of restorative justice (Braithwaite 2002, pp. 50$51,55,74,252-65) .{ }^{2}$ Unlike a criminal trial that assembles people who can inflict maximum damage to those on the other side of the case, the restorative justice conference assembles people who can offer maximum support to their own side, be it the victim's or the offender's. At a meeting of two communities of care, communication of disapproval comes from those personally affected by the crime, but more importantly from those who most love the offender. Nathan Harris's evidence from restorative justice conferences is that only disapproval communicated by people the offender most loves is effective in inducing remorse (Harris 2001, pp. 157-76). People who are well liked but not loved are not potent at inducing remorse. Nor are the police.

While an informal police caution for a first offense is a minimalist response in terms of taking the crime seriously, a restorative justice conference for a second offense escalates to a longer family and community ritual with a trained facilitator and a wider circle of participation by people concerned about the child. Such a conference becomes a focused way of supporting children. Are they struggling in school? If so, what support can the conference mobilize? Are they struggling in their relationships? Are their friends leading them into trouble? Is there support from other friends who steer them clear of such trouble? If there are problems with

\footnotetext{
2 This result is also evident in Wilson, Olaghere, and Kimbrell's (2017) meta-analysis finding that teen courts, impact panels, and reparative boards were ineffective forms of what some loosely call "restorative justice."
} 
alcohol, drugs, or anger management, proactive support may be needed. In this world of social support, every child leans on a "youth support circle." This is a restoratively elaborated version of parent-teacher conferences in schools that meet every year with every child over 12, with their extended family, and with well-networked elders until the child is helped to get his or her first job or get into college (Braithwaite 2001). The youth support circle is designed to reduce stigmatization of crime by being universal; children who never do anything wrong have them. In that world of a better-funded, more communal, welfare state, this conference for a second offense has no extra cost because it would be integrated into routine youth support conferences for building human capital, affecting only the timing of a conference that might normally be annual.

What about a third criminal offense? A longer restorative conference with a wider circle of participants is needed, usually with a follow-up conference to celebrate completion of an agreement. That would be more onerous than the conference for the second offense. More importantly, the next conference would see an escalation of social support for the child compared to the first conference. A child welfare worker would attend. The expertise a trained social worker would bring would include knowledge of the range of options available in the area for rehabilitation of the young offender. The social worker should also have a knowledge of principles of risk-need-responsivity in evidence-based selection of rehabilitation options (Andrews and Bonta 1998, 2010), a sound knowledge of the "what works" literature of criminology, and a good clinical capacity for responsiveness to the complexities of the specific case. In a restorative justice conference, it is not the job of the expert to dictate to a family (Pennell and Burford 2000). Restorative justice works by delivering stronger implementation of conference agreements enforced by the parties themselves than courts can achieve with police enforcement. This was the biggest effect size in the Canadian Department of Justice meta-analysis of restorative justice by Latimer, Dowden, and Muise (2001). The effects of completion of restorative justice agreements were much stronger than the statistically significant effect of restorative justice on reduced reoffending compared to control group members.

We can reconcile these results by understanding that if a restorative justice conference and a court both send a child to a counterproductive program, restorative justice will do more damage. The child will be more likely to complete the counterproductive program when it was agreed to by the family and other conference stakeholders than when the same 
outcome is ordered by the court. Restorative justice does greater harm than court when it agrees on counterproductive measures and greater good than court when it agrees on effective measures. The reason is that restorative justice is a superior delivery vehicle for rehabilitation programs.

The idea is to strengthen this comparative advantage of restorative conferences by investing in experts who speak up when the family considers sending the child to a boot camp, experts who point out that the evidence for the effectiveness of boot camps is discouraging (Lipsey 2009; MacKenzie and Farrington 2015). It follows from this that a good way to reanalyze a meta-analysis such as that by Lipsey (2009) would be to assess whether the combination of highly effective interventions such as social cognitive programs with restorative justice as their delivery vehicle increases effect sizes. Put more provocatively, it is not useful to compare effect sizes for restorative justice with those for other programs because it is better to conceive of restorative justice as a way of delivering multiple strategies. It makes more sense to compare restorative justice with a court as an alternative delivery vehicle of diverse correctional options, as in Strang et al. (2013). The bigger insights might come from teasing out which specific combinations of programs and delivery vehicles have positive and negative synergies, as is done in the business regulation literature (Gunningham, Grabosky, and Sinclair 1998).

A conference for a fourth offense might allow the family to mobilize rehabilitative options from further afield or expensive options that are rationed. Critics might query why such an expansion of the quantum of social support would make a difference given that in Lipsey's (2009, p. 141) meta-analysis of youth justice programs, providing more hours of services surprisingly did not increase the effect sizes of interventions. Restorative justice programs were the big exception to this result; hours of restorative service provision strongly increased the already statistically significant effect size of restorative justice in reducing reoffending. Within the "restorative justice" category of programs, those that included a mediation component, as opposed to simple restitution, also had an effect size more than one-third higher (Lipsey 2009, p. 142).

A conference for a fourth offense might also send the conference option to court for approval (or modification) by a judge. A meta-analysis from seven British studies led by Joanna Shapland concluded that restorative justice conferences have benefits that average eight times their costs (Strang et al. 2013, pp. 44-46). This result is a reason we do not 
consider costly escalation to court until a fourth offense. Yet isn't escalation to something less cost-effective at any stage surely inept? Actually, there is a relevant complexity of the evidence that should leave us open to this. While the Strang et al. review found that court is clearly less effective in preventing crime than restorative justice, it also suggested that a combination of court and conference could be more effective than either separately. More data are needed to assess if this is robust. The quantitative transitional justice literature finds that war crime prosecutions, truth (and reconciliation) commissions, and amnesties all have limited or contextual explanatory power on their own. However, when all three are used together, that country can experience a strong reduction in human rights abuses, at least if the truth commission engagement with civil society is wide and deep and if amnesties are qualified rather than blanket (Olsen, Payne, and Reiter 2010; Dancy et al. 2013; see also Sikkink 2011, pp. 184-87). The combined cost of a restorative justice conference that then reports to court might also be less than the sum of its parts if the integration can be designed to streamline court processing. This is essentially how the most comprehensive youth justice conferencing program in the world operates in New Zealand (Johnstone 2013).

At a fourth conference, when a young person and a victim are on the precipice of deeper trouble, escalated interventionist expectations can be assumed by the community of care. For example, in a 2014 interview I was told of a teenager in an Irish Republican Army area of Belfast who had repeatedly assaulted his mother. The restorative conference was conducted by Community Restorative Justice Northern Ireland. One part of the community restorative justice agreement, which had many parts, was that four community members agreed to respond immediately to calls for help from the mother and participated in training on how they could respond. These were not civil servants living far away, arriving the next morning. They lived around the corner and committed to respond promptly 24 hours a day. This is a good example of how restorative justice can expand to a wider, more immediate, more proximate web of social control and social support, while still providing a softer web than court enforcement to protect the mother by locking up her child.

By this point in our inexorability narrative, deterrence maximalists will be aghast that we are at a fifth criminal offense with no formally punitive response presumed. The offender has had "five free hits": the police restorative caution, followed by three restorative justice conferences, and then a first court appearance, all "doing nothing" for punitive deter- 
rence. Perhaps there will have been six if the first restorative caution was preceded by an informal warning on the run.

Contrary to maximalist fears, offenders do not perceive restorative justice conferences as "doing nothing," but as a grueling experience of meeting their victims in the presence of their loved ones (Umbreit and Coates 1992; Schiff 1999). Deterrence maximalists are wrong to see imprisonment as the only kind of perceptually tough response. Perceptually, the process is the punishment, as the title of Malcolm Feeley's (1979) book attests, especially when the process is designed with a ritual seriousness that is emotionally demanding.

\section{Dynamic Deterrence and Defiance}

The Sword of Damocles is an ancient metaphor popularized by the Roman republican philosopher Cicero (1877, pp. 185-86). He based it on the story of Dionysius II, a Sicilian king of the fourth and fifth centuries BCE, who hung a sword attached by a horsehair above the head of a courtier called Damocles who envied the king. The ruler wanted to illustrate the insecurity of being king. Today, the Sword of Damocles generally refers to any ever-present peril hanging over the head of a person. The existence of an ever-present peril is an important element of minimally sufficient deterrence.

\section{A. Preserving the Sword}

At the court appearance for a fifth offense in a criminal career, the court might signal that a sword hangs over the child or young adult. This is not best done as a threat. The power of the sword, according to Cicero, is not that it falls or is threatened; its power is that it hangs. The regulatory literature shows that the better signaling is for the judge to say at the outset of the court hearing for a fifth offense that its objective is to support the family and save them from having their child taken away. Perhaps only later than a fifth offense and only after an offense that is very serious would the judge ask whether the offender would think it reasonable that she be incarcerated to protect the community if she were to commit another offense of such seriousness. ${ }^{3}$ The objective at that later trial is to open the

\footnotetext{
${ }^{3}$ Note the use of motivational interviewing techniques here, which are empirically established as techniques that are effective and that avert threat making (Rubak et al. 2005; Lundahl et al. 2010).
} 
mind of the offender to the reasonableness of the community protecting itself with a custodial sentence. The idea at the next trial for the next serious offense would be to remind the offender that she herself in her last appearance said that a custodial sentence would be reasonable if an offense of this seriousness recurred. The judge would then concede the offender's point of view but mobilize social support for one last chance to stay in the community, while making it clear that next time she was likely to agree with the incapacitation recourse that the offender herself had concluded was reasonable in these circumstances.

At every stage, the minimally sufficient approach requires that the offender be led to see a new escalation of social support provided in response to a new transgression, but also a slippery slope toward a set of punitive options with life imprisonment at the peak of the pyramid. Of course, community service orders, fines, electronically monitored home detention, orders to a violent husband to transfer bank accounts to his wife so she has the financial capacity to leave him, and a diverse variety of other options that are found lower in the pyramid are available as alternatives to prison. The sheer diversity of community gifts of support conveys a message of care when it includes, for example, the Royal Society for the Protection of Cruelty to Animals program in Australia, which guarantees care to the pets of domestic violence victims who stay in abusive relationships to care for their pets or to the pets of offenders who are required to move out. The escalation of support as a life careens into deeper trouble is a way of increasing the legitimacy of more severe sanctions as a last resort when escalation to them does occur. It is also a strategy for combating the widespread perception of criminal offenders in many societies that the system lets you get away with it for years and then one day out of the blue locks you up. The proposal is inexorable both in escalating support and in the way it signals a move to escalating deterrence.

Why reserve court appearances until a fourth official detected offense? Why reserve serious sanctions for later still in a criminal career? One reason is the evidence from the Canberra randomized controlled trials of restorative justice led by Lawrence Sherman and Heather Strang. Offenders randomly assigned to restorative justice had greater fear of future criminal enforcement after a restorative justice experience than did offenders randomly assigned to criminal prosecution after their criminal trials (Braithwaite 2002, pp. 119-22). Offenders emerged from their restorative conferences more fearful that they would be rearrested if they offended again, more fearful of family and friends finding out, and more 
fearful of a future conference, compared to those assigned to court (Sherman and Strang 1997; Sherman et al. 1998). Minimally sufficient deterrence favors restorative justice for multiple early offenses in a criminal career because restorative justice sharpens the Sword of Damocles. Criminal trials blunt the sword hanging over the offender. After bringing down the courtroom sword, it loses mystique. The criminal trial in current judicial practice blunts the Sword of Damocles because in the majority of nonserious cases the offender is surprised at how easily she gets off as the court struggles with its system capacity overload.

The minimally sufficient deterrence idea is to hold the trial in reserve until it is time to take the case very seriously by projecting a clear trajectory of escalation to an ever bigger Sword of Damocles that is being averted by more and more support. Among other objectives, this support is intended to make that sharpening sword appear ever more just. Other kinds of criminological evidence support a Sword of Damocles effect (Sherman 1992, 2011), including Dunford's (1990) finding that a warrant for arrest deterred domestic violence substantially better than either actual arrest or nonarrest. The theoretical perspective of minimal sufficiency is that warrants for arrest have great attractions over actual arrest and that deferred prosecutions are more powerful tools than actual prosecutions. These are problem-solving tools that can enable support to play a larger role than sanctions. Concluding that deferred prosecutions are in principle powerful tools is not to deny that their widespread use in corporate criminal law has often approximated doing nothing in matters of a seriousness that called for doing quite a lot (Eisinger 2017).

\section{B. Dynamic Deterrence That Accounts for Defiance}

Responsive regulatory theory argues that the passive deterrence thinking of the law and economics tradition, as in Gary Becker's (1993) Nobel Prize-winning work, has limited value. The reason is that real-world deterrence unfolds dynamically. Dynamic deterrence moves through sequences of threats; passive deterrence is static, involving levels of threat that are constant across time. International relations theorists have been more dynamically sophisticated than criminologists and economists of deterrence. They do not assume that, even though the United States has a bigger deterrent arsenal than the rest of the world's militaries, it works for the United States to say to another country "Do what we say or else!" There is evidence aplenty, from countries as close as Cuba, that threats are 
as likely to induce defiance as compliance. This is accepted even by conservative writers like Michael Rubin who oppose dialogue with "rogue states." Rubin (2014, p. 4) nevertheless conceived of Cuba, North Korea, Iran, Iraq, and Libya as "backlash states" that were "defiant." Former US Defense Secretary William Cohen tweaked this definition of rogue states to conceive of them as regimes "immune to traditional deterrence" (Rubin 2014, p. 4). While demands for compliance backed by passive deterrence work poorly in international affairs, when the United States dynamically escalates its deterrent power around a weaker country, as it did during the Cuban missile crisis, it can get a deterrent result (dismantled Cuban missiles). Of course, dynamic escalation of deterrence in international affairs is a dangerous game because little Cuba might mobilize powerful friends to dynamic escalation of their deterrent capabilities in response. Little Serbia did manage to dynamically escalate catastrophic deterrence by triggering the escalation to World War I after the assassination of Archduke Ferdinand by its citizens.

Psychologists of learning approach the way punishments work as dynamic learning sequences that are beyond the writ of static deterrence models. They demonstrated psychological reactance to threats (Brehm and Brehm 1981). Defiance is a more elegant term that Sherman (1992) deployed to describe this phenomenon.

A paradox of the pyramid is that by being able to escalate to tough responses at its peak, more of the regulatory action can be driven down to its deliberative base. Yet punishment, according to responsive regulatory theory, simultaneously increases deterrence and defiance. Figure 2 is a way of summarizing the implications of more than 50 experiments on defiance originally conducted by Brehm and Brehm (1981) and their colleagues, and many more since (e.g., Rains 2013). At low levels of punishment, defiance usually exceeds deterrence. Figure 2 expresses this as the resistance effect exceeding the capitulation effect at lower levels of coercion. The dashed line is the net compliance effect represented as a sum of the resistance score and the capitulation score. Only when punishment bites very deeply at the peak of the pyramid, resulting in many giving up on resistance, does the deterrence effect exceed the defiance effect.

Yet escalation only as far as the lower levels of the pyramid can elicit compliance when that first step up the ladder is seen as a signal of willingness to redeem the regulator's promise to keep climbing until the problem is fixed. Put another way, the first escalation becomes a wake-up call that convinces the offender that she or he is on a slippery slope. Social support 


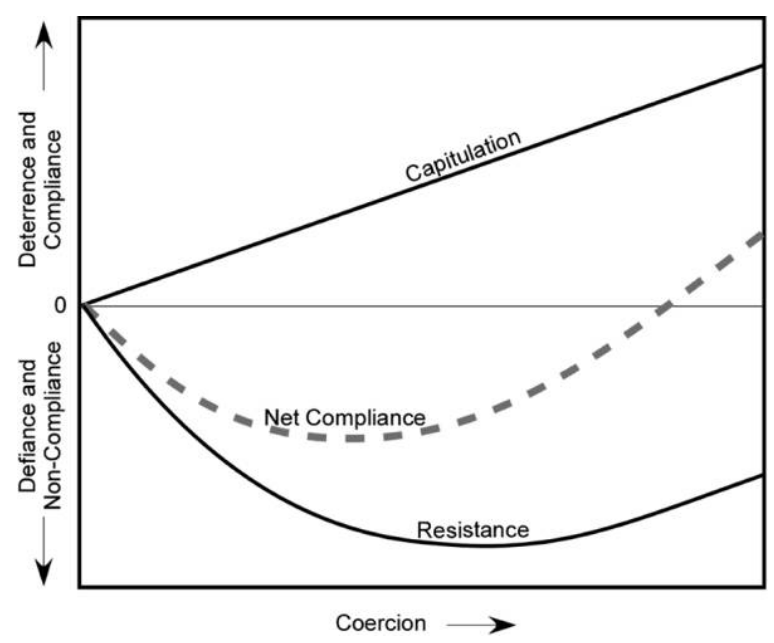

FIG. 2.-A theory of the effect of coercion on compliance as the net result of a capitulation effect and a defiant resistance effect. Source: Based loosely on experiments summarized by Brehm and Brehm (1981).

initiatives also help by signaling that paths off that slope are available. Perception of the dynamic inexorability of the pyramid does most deterrence work, not the passive general deterrent. Not only does the specific passive deterrent at low levels of the pyramid of sanctions fail to deter very effectively; it mostly engenders more defiance than deterrence.

Redundancy in the design of the pyramid also saves the day when defiance effects initially exceed deterrence effects. The redundancy idea is that all regulatory tools have deep dangers of counterproductivity. Therefore, one must deploy a mix of regulatory tools with heavy representation of dialogue and social support in the mix. The best way to deploy the mix is dynamically, so that, in sequence, the strengths of one tool have a chance to cover the weaknesses of another. For example, the pyramid in figure 1 is about the strengths of one form of restorative justice covering the weaknesses of other forms of restorative justice, the strengths of deterrence covering the weaknesses of restorative justice, the strengths of incapacitation covering the weaknesses of deterrence, and the strengths of strong social support covering the weaknesses of limp social support.

The risk of defiance exceeding deterrence is one reason that the peak of the pyramid should always be threatening in the background but not directly threatened in the foreground. Making threats increases defi- 
ance, turning the defiance curve in figure 2 more steeply downward. How then can police and judges be threatening in the background without making threats? One way is by being transparent for the first time that the pyramid is the new policy that precedes escalation. Law enforcers must be the change they want to see. They achieve this by communicating openly with society about the design policy of the pyramid. By inviting citizens to be partners in the democratic design of different regulatory pyramids for responding to different crime problems, citizens also come to learn about the inexorability of escalation until there is compliance with the law. The ideal is to communicate the inexorability of deterrence in this way rather than by making threats in specific cases.

\section{Dynamic Deterrence as a Remedy to Enforcement Swamping}

A dependable, inexorable peak to the pyramid is a particular way of thinking about what Mark Kleiman (2009) calls dynamic concentration of deterrence, often called (in a misleadingly static way) focused deterrence. ${ }^{4}$ For responsive regulation, the dynamic concentration of deterrence potency is at the rarely used peak of the pyramid. Kleiman, like David Kennedy (2009), reached a conclusion similar to responsive regulatory theory about the superiority of dynamic over passive deterrence through contemplating how to respond to enforcement swamping as a challenge for thinly resourced policing agencies.

Kleiman's dynamic concentration theory shows why abandoning random targeting in favor of a strategic concentration of targeting can work as long as monitoring works. In the simple case of scarce resources enabling targeting of only one of two regulated actors, the intuition that "concentrating on $\mathrm{Al}$ would allow Bob to run wild" is wrong. If $\mathrm{Al}$ is

\footnotetext{
${ }^{4}$ The danger of describing the theory behind innovations like Operation Ceasefire as "focused deterrence" is that it will be understood as a static policy of identifying the highest risk group for targeting. Even the principal authors of the strategy, who clearly understand its dynamic qualities, often describe a static deterrence targeting strategy, complemented by short breakouts into discussing its dynamic aspects (Kennedy, Kleiman, and Braga 2017). The most common mistake business regulators make concerning responsive regulation is to understand it as a static policy of triaging the highest risk groups for targeting with more deterrent strategies. The point of reframing deterrence is to push criminologists away from such static ways of thinking. Minimally sufficient deterrence commends restorative justice as an alternative to prison even in the highest-risk circumstances such as creeping genocide, actual genocide, or murders that risk further revenge killings (e.g., Braithwaite and Gohar 2014).
} 
promised certain punishment, a rational $\mathrm{Al}$ will comply as long as compliance costs are less than penalties. "Then Bob, seeing that $\mathrm{Al}$ has complied, will himself comply; otherwise Bob knows that he would certainly be punished. So giving priority to $\mathrm{Al}$ actually increases pressure on Bob." In this we see the dynamic elements of the strategy. Kleiman (2009, p. 54) shows that this initial insight holds for a variety of conditions such as promising certain punishment of the second mover rather than the first and larger numbers of players. Dynamic concentration helps a little punishment go a long way.

Tax authorities have also learned how to respond to massive enforcement swamping when rich people, trusts, and companies follow their herds into illegal tax shelters. This is to announce that while the tax authority lacks the resources to enforce the law against all who stampede into shelters, they can prosecute the first risk taker to jump into a shelter after the date of their announcement of intent to attack particular shelters in the courts. This can be extremely effective in ending cascades of risky tax cheating by high-wealth individuals and corporations (Braithwaite 2005). Braithwaite (2012) discovered the same dynamic concentration in the wisdom of generals who face the biggest enforcement swamping challenge in the world today: small numbers of UN peacekeepers facing Africa's worst war in the Democratic Republic of Congo.

As usual, practitioners here were ahead of theory. Tax officials were ahead of us, as were those generals in Congo and that Texas ranger on the screen in our youth. The ranger faces a lynch mob with one bullet in his gun. He turns them away with the promise "the first to step forward dies." Kleiman (2009, pp. 49-67) elegantly theorizes why the dynamic concentration of deterrence by the Texas ranger works. A meta-analysis of 10 quasi-experimental and one randomized controlled trial of dynamic concentration found consistent effectiveness across studies and a medium-sized statistically significant crime reduction effect overall (Braga and Weisburd 2012, 2014; Weisburd, Farrington, and Gill 2017). The intuition that concentrating deterrence on Max will allow Mary to run wild turns out to be wrong in terms of rational choice theory (Kleiman 2009, pp. 49-67) and empirically wrong according to Braga, Apel, and Welsh (2013, p. 315), who found that with dynamically concentrated deterrence, "vicariously treated gangs were deterred by the treatment experiences of their rivals and allies." Dynamic focusing at the peak of a pyramid is just one way of concentrating limited enforcement resources that delivers dynamism to both specific and general deterrence. 


\section{Dynamically Raising the Bar Serious Offenders Must Fump}

Boston's Operation Ceasefire is criminology's locus classicus of the dynamic concentration of deterrence in showing how an inner-city justice system overwhelmed by the frequency of gang violence reduced homicide (Kennedy 2009). It was also "focused deterrence" in that it did not attempt to deter all crimes perpetrated by gang members, but only their gun crimes. My hypothesis is that the passively focused features of Operation Ceasefire may have some value, but its dynamic concentration of deterrence is more innovative and more germinal. It follows that a rerunning and updating of the encouraging Braga and Weisburd (2012) meta-analysis are needed to compare those interventions that were simply focused and passive in their deterrence with those in which the intervention also delivered a dynamic concentration of deterrence. The dynamic concentration aspect of Operation Ceasefire involved the Texas ranger trope described above. Police sat down in meetings with gang leaders and gangs to let them know, in effect, that we know that you know that we do not have the capacity to go after all of you for all your sins. But we do have the capacity to go after all the offenses, and all the parole and probation breaches, of all the members of the next gang to use a firearm in a crime. This means that instead of concentrating deterrence on the worst offenders, deterrence was dynamically concentrated on the first offender to use a firearm after the announcement date. The theory of the intervention was that all gangs would self-regulate gun carrying and use to avoid being the first gang to be targeted or the second gang to be targeted after the first. The ethnographic side of the evidence on the formidable desistance of these gangs from gun use seems to support this hope (Kennedy 2009). For proportionality theorists, it is of course a weakness of the program that it diverts resources from prosecuting the most serious offenses to what might be minor parole violations after a gang uses guns. ${ }^{5}$

Operation Ceasefire was in tension with the minimally sufficient deterrence model in two ways, however. First, the approach was thin on restorative justice and social support as approaches that strengthen a deterrence strategy into which restorative justice and social support are integrated. There was certainly dialogue with gang members involved, and pathways out of the gang were discussed and even provided for some;

\footnotetext{
5 This critique also applies to responsive regulation. It has been eloquently advanced by Karen Yeung (2004).
} 
but from the perspective of minimally sufficient deterrence, it was too narrowly oriented to pulling levers to make deterrence more "swift and certain" for a strategically targeted subgroup. There are reasons to suspect that in some of these programs this swift and certain deterrence may have been communicated with Trumpian threats, which risk being counterproductive according to minimal sufficiency theory, defiance theory, and the theory of motivational interviewing.

There was insufficient attention in Operation Ceasefire to a dynamic approach to support. Under the minimally sufficient deterrence model, support peaks during the period in which desistance is setting in. I am inclined to read protests from the leaders of the innovation that this is not true as overstated and revisionist (Kennedy, Kleiman, and Braga 2017). That matters little. If moderately violent societies like the United States are to learn how to manage their hot spots better from experience with peacekeeping in extremely violent societies like Congo, we might be able to build a consensus for dynamic concentration of support to become more prominent than dynamic concentration of deterrence. This policy lesson has been better learned in international peacekeeping and peace building than in national policing to control organized violence (Braithwaite and D'Costa 2018, chap. 3). The lesson is that desistance should not only cause a lifting of punishment; the strategy should also maximally concentrate rewards at the moment of desistance. The rewards are not only tangible matters of vocational training and job placement, but also rituals of pride at celebration conferences in which loved ones eulogize peacemaking and rehearse redemption scripts (Maruna 2001).

Project HOPE is a drug court program in the focused deterrence tradition that initially seemed to have promising pyramidal features of escalated response targeted on hard cases. HOPE stood for Hawai'i Opportunity Probation with Enforcement. It has been adopted in dozens of US locations with Honest replacing Hawai'i, yet with mostly very limited investment in creating job or other "opportunities." Intervention escalated as drug users went off the rails. Yet it may be the program that ran off the rails; much of the rhetoric of its practitioners was maximalist, oriented to "swift and certain" deterrence. This happened when the evidence is not supportive of criminal justice swiftness, even though swiftness of parental response in child-rearing is important (Pratt and Turanovic 2018).

Hawken and Kleiman (2009) entitle their evaluation Managing Drug Involved Probationers with Swift and Certain Sanctions: Evaluating Hawaii's 
HOPE. Duriez, Cullen, and Manchak (2014) raise the concern that the ideology driving the diffusion of Project HOPE has emphasized its "swift and certain" character, ignoring other positive features such as motivational interviewing training for officers in the program, something for which there is a strong evidence base (Rubak et al. 2005; Lundahl et al. 2010), which is why motivational interviewing has become central to responsive regulation (Braithwaite 2011). The literature reviews of HOPE can be characterized as somewhere between showing great promise and being discouraging (Lattimore et al. 2016). ${ }^{6}$ As with Operation Ceasefire, they should be redone after some on-the-ground engagement with what each specific program actually does. They could be coded qualitatively or quantitatively according to four variables: how much deterrence is involved (HOPE's E: "Enforcement"), how much social support there is (HOPE's $\mathrm{O}$ : "Opportunity"), how dynamically concentrated the deterrence is, and how dynamically concentrated the support is. Meta-analyses might contribute more to science if they were more theoretically focused on what they evaluate and less focused on heterogeneous puzzles like HOPE that are in essence brands.

The second tension between minimally sufficient deterrence and Operation Ceasefire is that an approach that says your gang will be seriously targeted intensively only if it uses guns challenges the inexorability principle. In an enforcement swamping crisis, however, we must confront the reality that priorities must be set that start where it is most important to start. In Democratic Republic of Congo, that priority was mass rape atrocities in which hundreds of women and children were sometimes raped, murdered, or enslaved into mines (Braithwaite 2012). At least one peacekeeping commander was effective in reducing this seemingly impossible enforcement swamping crisis during the first decade of this century, according to my Congo fieldwork. He convinced assembled militant leaders that the next militant group to commit a mass rape atrocity would be the group on which peacekeepers would focus all their military capabilities to bring perpetrators to trial. In my Congo fieldwork trips early in this decade, I reproached the head of MONUSCO, the military com-

\footnotetext{
${ }^{6}$ Lattimore et al. (2016, p. 1103) describe the HOPE program they evaluated at four sites as a "program that emphasizes close monitoring; frequent drug testing; and swift, certain, and fair (SCF) sanctioning. It also reserves scarce treatment resources for those most in need." There is not much escalation of support in that description, nor any dynamic distinctiveness of the deterrence strategy to transcend the limits of static deterrence.
} 
mander, the deputy commander, the general in charge of the relevant region, and the US ambassador for failure to implement this strategy against Colonel Cheka of Mai Mai Cheka, allegedly the worst perpetrator of mass rape atrocities, and some others like him. Within a year of the appearance of publications that discussed this (e.g., Braithwaite 2012), the United Nations announced a policy shift in the direction of dynamic concentration of deterrence, though this had nothing to do with the publications. The consensus of knowledgeable commentators is that this quickly improved the security of the people of Congo after 2014, particularly through the surrender of the M23 armed group that in 2012 captured Goma, a strategic city with a population of a million that is now liberated. In 2017 after almost 3 years of sustained military pressure to force surrender to face trial, Cheka turned himself in. That is no more than suggestive qualitative evidence for dynamic concentration of deterrence from the least likely case (Eckstein 1975) of probably the world's most extreme and persistent enforcement swamping crisis in recent decades.

Gun violence was obviously a good target for Operation Ceasefire. It produced a wonderful result in reducing shootings and homicide by more than 30 percent, a result that continued to be supported in more recent work on dynamic concentration of deterrence on US gang violence (Braga, Apel, and Welsh 2013; Kennedy, Kleiman, and Braga 2017). The strategy, however, fails the inexorability test of minimally sufficient deterrence because inexorability happens only for the particular offense in focus (usually gun crime). Prioritizing of greatest harm is desirable and might not deeply threaten inexorability as long as there is a strategy to move on to clean up one kind of gang crime after another, to move down to the B-list of gang harms and then a C-list after the A-list of gun homicide harms has been tamed. ${ }^{7}$ Then a strategy like Operation Ceasefire perhaps in the long run could pass the inexorability test; likewise with enforcement swamping crises with tax shelters that the United States and Australia have faced in recent decades. Australia learned that it is possible gradually to raise the bar on tax compliance obligations. This is achieved by targeting the 10 worst tax compliers each year, a different 10 each year because last year's terrible 10 are no longer so terrible this year:

\footnotetext{
${ }^{7}$ At times, practitioners speak of A-lists and B-lists in static terms, by e.g. arguing that police go after an A-list of the most serious offenders for automatic prosecution, putting only the B-list into an Operation Ceasefire or a deferred prosecution program.
} 
When the judgment is made that there is a culture of tax cheating in a particular market segment, the industry norm revealed in the multivariate analysis is still used to target those furthest below the norm for audit and other compliance tools. But more of them can be targeted than in other industries. And when they are caught out by the audit, the bar they are required to reach before they are released from targeted surveillance can be raised a little higher than the industry norm. As a result of the worst 10 compliers in the industry moving from way below the old norm to above it, the norm of course is moved upwards. Then in the next year, a new set of the worst 10 in the industry is moved up above that higher norm. This raises the bar again. We can in this way keep raising the bar with problem industries until they are paying their fair share. (Braithwaite 2005, p. 160)

Stampedes of the wealthy into tax shelter booms do end, as they did in Australia in the late 1970s and again around 2000 (Braithwaite 2005). Cascades of open-air drug markets taking over the great cities, even the stairs of the New York Public Library, also end, and that contributed to the downward cascade of homicide in Manhattan (Zimring 2011). Consider a brief list of accomplishments in reversing catastrophic cascades. The ozone hole was substantially closed even though it seemed unstoppable until the Montreal Protocol started to reverse the cascade into chemicals that were widening it (Kuttippurath and Nair 2017). Resources were provided to developing countries to comply with the Montreal Protocol after 1987, and there were diplomatic shots across their bows as well, particularly by US embassies (Braithwaite and Drahos 2000, pp. 261-67). Perhaps too late, perhaps not, today we see at least the beginnings of reverse cascades from coal to solar. President Kennedy predicted a cascade of 1525 nuclear powers by the 1970s; yet there are still only the United States, Russia, China, the United Kingdom, France, Israel, India, Pakistan, and North Korea thanks to civilizing forces in international civil society that won a 2017 Nobel Peace Prize and dogged regulatory inspection in places like Iraq under the nuclear nonproliferation regime (Braithwaite and Drahos 2000, p. 318). Interminable civil wars in the places where the worst wars have cascaded for longest, such as Democratic Republic of Congo, will also one day reverse to cascades of peace.

The trend in regulatory theory is to conceive ever greater sophistication in risk assessment and risk management as the main game of how best to cope with the seemingly impossible challenges of regulatory enforcement swamping (Black and Baldwin 2010). Though this is not to- 
tally wrong, I suspect we learn most from worst cases like Cambodia after its multiple cascades of genocidal violence beyond the 1970s. In the 1990s, particularly since 1998, downward cascades of violence began to spread in Cambodia that Broadhurst, Bouhours, and Bouhours (2015, 2018) described as a dynamic "civilizing process" (Elias 1978; Pinker 2011). Broadhurst and his colleagues document that local police and UN peacekeepers did useful things to help trigger the reverse cascades. As they show with Cambodia, as a least likely case (Eckstein 1975), it is not so much that police were geniuses of risk analysis. Rather they did something that Malcolm Sparrow (2000) simply describes as pick some important problems and fix them.

Cambodia was more a matter of return to long-run momentum toward civilizing processes that citizens crave and governments pursue when they seek legitimacy from citizens and with the international community. This was combined with police and peacekeepers helping out with an A-list of violence problems that they helped clean up, eventually moving on to B- and C-lists. A-list criminality included robbery, homicide, and kidnapping, with cattle theft being high on the B-list because this can be financially devastating in rural areas. Local police became quite popular according to Broadhurst and his colleagues and gradually moved away from putting bullets in the heads of desperados and toward peacetime policing.

We can learn from local priests in Rwanda who acted like Texas rangers without even a single bullet in the midst of Rwanda's cascade of genocide. The priests stood their ground, stopping the genocide from spreading to their community through their emotional dominance in insisting that their church would not stand for this in their village (Klusemann 2012). Other priests who tried this were hacked down. Together, long-run civilizing processes helped by dynamic concentrations of sanctions and support and gradually raising the bar on what kinds of violence are intolerable eventually can pacify even a Cambodia or a Rwanda or close an ozone hole. This can be done without filling prisons. ${ }^{8}$ Or so I hypothesize.

\footnotetext{
${ }^{8}$ Rwanda did fill its prisons with 126,000 charged with participation in its 1995 genocide. Many were children who were raped in prison and died from HIV-AIDS. Many others were innocents forced to participate after seeing their family members hacked to death for refusing. Defendants were executed on the judgments of second-year law students. In the end, that tiny, poor society did not have the capacity to deliver justice to 126,000 for such serious crimes. Most were released to face traditional gacaca, which some of the time was somewhat restorative in approach (Clark 2010).
} 
IV. Conversations across the Curriculum of Crimes Restorative justice principles are useful to a minimally sufficient deterrence strategy because defiance (Sherman 1992, 2011) is a critical risk. Defiance is reduced when communities of care do most of the work. Nathan Harris found that perceived informal disapproval of those most loved inside restorative justice conferences, not of criminal justice actors, does the work of persuading offenders that their crime is shameful, persuading them to remorse and repair of the harm to victims and to their own family (Harris 2001, pp. 157-76). In restorative justice, there is no need for anyone to invoke the concept of shame or for anyone directly to shame offenders. Loved ones discussing how concerned they are about the consequences of the crime, the suffering of victims, and what the family can do to help repair the harm is the way to elicit remorse without defiance. Motivational interviewing of these loved ones can draw this out.

Conversely, there is evidence that stigmatization (as opposed to reintegrative shaming) increases crime in criminal justice processes (Ahmed et al. 2001; Braithwaite, Ahmed, and Braithwaite 2006; Tyler et al. 2007) and in business regulation (Makkai and Braithwaite 1994; Harris 2017). Stigmatized offenders are treated as bad people who have done bad things, while reintegratively shamed offenders are treated as essentially good people who have done a bad thing. Stigmatized offenders are cast out from the community of the law-abiding without paying attention to reintegration rituals that might have drawn them back into the law-abiding community. Aversion of stigmatization is critical to an effective package of minimally sufficient deterrence.

The theory of reintegrative shaming argues that shame is important to crime control and to problem solving (Leach and Cidam 2015; Spruit et al. 2016). Societies in which rape is not shameful will have a lot of rape. Societies in which feminist politics communicates the shamefulness of rape and domestic violence can enjoy steeply reduced rates of these crimes, as Pinker's (2011, pp. 196-201) analyses of declining rates of rape and domestic violence and growing shamefulness of these crimes in certain Western societies suggest. Broadhurst, Bouhours, and Bouhours (2015, pp. 310-13) likewise diagnose repeated surveys in Myanmar since 1996 to show declining domestic violence, growing disapproval of wife beating, and growing public awareness campaigns about why it is wrong. Feminist politics is just one kind of engagement around the shamefulness of certain crimes. 
One of the virtues of deliberative forms of justice such as restorative justice is that they increase the active participation of citizens in their democracy through the judicial branch of governance, through children's participation in antibullying programs in schools, and through involvement of environmental activists and fishermen in the regulation of environmental crimes. Restorative justice therefore has a role to play in educating citizens in the curriculum of crimes and why they are shameful, through their participation in restorative conversations about the crimes of their classmates, their neighbors, their family members, and themselves.

Existing criminal justice institutions by contrast are overly professionalized. One consequence is they provide no space for democratic deliberation with the young about why crimes that affect people are wrong and what should be done about them. Democratic citizens can sit in the public gallery for criminal trials, but few do; and if they try to participate in the conversation about the rights and wrongs of the matter from the gallery, they are silenced.

Penal populism that increases punitiveness is certainly a risk within contemporary criminal law jurisprudence (Lacey 2008). Advocacy for minimally sufficient deterrence, however, is advocacy of quite a radical transformation of these dysfunctional institutions. Ordinary people are more punitive than the courts when they read accounts of cases and sentences in the media. When they read about the rich complexity of the same case as the judge hears it, they recommend sentences similar to those of the judge. The more information they have, the less punitive they are (Doob and Roberts 1983, 1988). When citizens have the chance to engage directly with offenders and the complexity of their circumstances in a restorative conference, their vengefulness reduces even further (Strang et al. 2013, pp. 40-42), which explains why restorative justice conferences produce less punitive outcomes on average than does traditional criminal justice processing (Braithwaite 2002, pp. 146-48).

In sum, the restorative justice component of minimally sufficient deterrence calms defiance, helps educate offenders and the entire community to the shamefulness of crime and to the curriculum of crimes, while laying foundations for minimal sufficiency of punishment that can defeat penal populism's maximalist politics. A utopian world can be imagined in which each year 1 percent of the population took responsibility for an offense in a restorative justice conference conducted by the criminal jus- 
tice system, a school, a university, or a workplace. If 10 supporters of victims or offenders attended each conference, conversations about the curriculum of crimes would ripple across 10 percent of the population each year. Because human beings are story-telling animals, we learn the shamefulness of the curriculum of crimes through participating in, and retelling, stories of which we are a part. This retelling can do most of the work of constituting the curriculum of crimes, especially when newer crimes such as profit shifting by multinational corporations begin to become transparent. Consciences are formed by operation of "the criminal law as a moral eye-opener" (Andenaes 1974, pp. 116-17), especially when shamefulness is suppressed through a politics of domination with crimes such as torture and sexual and gender-based violence.

\section{Minimal Sufficiency of General Deterrence}

The preceding section was partly about the general deterrence that arises from citizens talking with one another about why something like rape or torture is wrong. Reintegrative shaming theory advances the idea that general deterrence by means of the internalization of shame (anticipated self-shaming rather than shame sanctions) combined with a path out of shame (Leach and Cidam 2015; Spruit et al. 2016) is more important than deterrence by sentences handed down by courts (Ahmed et al. 2001). It is also about the restorative justice political strategy for community support for a less punitive justice system. Satisfaction with the justice, with the respect for victim rights, and with the effectiveness of restorative justice in crime prevention is high (normally over 80 percent) for citizens who sit in on restorative justice conferences (Braithwaite 2002, pp. 45-71; Wilson, Olaghere, and Kimbrell 2017). Part of the practical politics of driving punishment down to minimally sufficient deterrence is convincing politicians who see restorative justice as a soft option to sit in on a conference and chat afterward with the participants. This is important because democratic politics is the key constraint on whether and how judges or police can use minimally sufficient deterrence.

The literature on the consequences of police strikes (Andenaes 1974) has long persuaded criminologists that crime spikes when deterrence is taken off the table. The contention of minimally sufficient deterrence is that courts will have little to do in delivering minimally sufficient general deterrence if citizens are empowered conversationally about the shame- 
fulness of the curriculum of crimes (Braithwaite 1989, pp. 77-79). Courts have to ensure through some form of incapacitation that the community is protected from modest numbers of people who are a severe danger to the community. The hypothesis is that minimally sufficient deterrence will be provided by general deterrence resulting from incapacitation cases, combined with others in which repeated failures of social support and moderate deterrents escalate to severe deterrents toward the peak of a pyramid.

This hypothesis has not been empirically tested, but it is consistent with the evidence that, as long as deterrence does not fall to zero, increasing average prison terms does not have much effect in reducing crime (Nagin 2013; Chalfin and McCrary 2017). It seems unlikely that a society would face crime risks from insufficient passive general deterrence if it takes seriously shame management and education about the curriculum of crimes and if it puts into place a credible peak as a last resort in its pyramid of dynamic deterrence. We cannot completely do without passive general deterrence, but a minimally sufficient quantum of it delivered by the model I propose here may be enough to achieve the limited work general deterrence can do.

My proposals can be accomplished only incrementally; learning through monitoring is important to reveal any explosion of crime driven by a deficit in passive general deterrence (Braithwaite and Pettit 1990, pp. 14055; Dorf and Sabel 1998). If and when empirical evidence suggested this was happening, incremental movement could be halted and adjusted to bolster passive general deterrence. My prediction, however, is that as societies such as the United States and Russia with imprisonment rates over 600 per 100,000 reduce their passive general deterrence toward that of societies such as India, Indonesia, and Japan with imprisonment rates in the 30 s to 40 s, passive deterrence deficits will not cause crime waves. This is suggested by cross-national comparisons of crime that show that low incarceration societies, many in Asia, often have low crime rates.

\section{Conclusion}

Inexorability is a core principle of minimally sufficient deterrence: pursue inexorable consistency of detection and disapproval of predatory crime. This implies fusing the debate on dynamic concentration of deterrence with the debate about less prison and more and better police. 
Indeed, the move away from the nihilism about policing prevalent at the time of the Kansas City Preventive Patrol Experiment is a light on the hill for criminologists (Nagin, Solow, and Lum 2015). So is the move away from nihilism about rehabilitation that was prevalent at the time of "Nothing Works" (Lipton, Martinson, and Wilks 1975). Policing and rehabilitation are useless only if they are unresponsively deployed. For example, evidence-based refinement of responsivity of rehabilitation can improve the menu of options in the pyramid of support in figure 1 (Andrews and Bonta 1998, 2010; Manchak and Cullen 2015). Developmentalists have convincingly shown that social support is important to crime prevention long before the first offense occurs (Cullen 1994). This is a vital piece for any integrated theory of crime prevention. My arguments here on minimally sufficient deterrence are, however, limited to an integrated strategy of deterrence. Deterrence is far from the most important element of a sophisticated strategy to protect citizens from crime.

I have introduced suggestive evidence that an inexorably supportive firm hand might help in preventing crime, in preventing the collapse of welfare states that struggle to deter corporate tax evasion, and in addressing many other challenges of crime control. ${ }^{9}$ The white-collar crime piece of this is important because, as Sutherland ([1949] 1983) instructed, any theory of crime that provides an account of crimes of the powerless but not of crimes of the powerful is troubling, indeed profoundly misleading. It might be credible as a theory of something more specific than crime. Moreover, the dominance of theories in criminology that fail this test means criminology buttresses oppression when it normalizes prisons that hold tiny proportions of wealthy white criminals.

The evidence adduced in support of minimally sufficient deterrence is no more than suggestive. It is common for criminological theories to have something going for them while being wrong in most contexts. Until minimally sufficient deterrence is subjected to an array of different kinds of empirical investigations, this may be as true of it as it is of theories of passive deterrence that currently dominate thinking. I have attempted to show that minimally sufficient deterrence has promise as a strategy for moving from passive to dynamic deterrence because it starts

\footnotetext{
${ }^{9}$ For a more developed analysis of the empirical evidence for and against restorative justice and responsive regulation, see Braithwaite (2016) and more recent meta-analyses by Wong et al. (2016), Bouffard, Cooper, and Bergseth (2017), and Wilson, Olaghere, and Kimbrell (2017), all of which show significant, usually moderate, effects of restorative justice in reducing reoffending.
} 
from what we already know about deterrence and defiance, and because it integrates insights from other relational theories that each enjoy a body of empirical support. These are theories of social support (Cullen 1994), responsivity (Andrews and Bonta 1998, 2010), responsive regulation (Braithwaite 2008), sharpening the Sword of Damocles (Dunford 1990; Sherman 1992, 2011), dynamic concentration of deterrence (Kleiman 2009), and shame and pride management (Ahmed et al. 2001) combined with indirect reciprocity (Berger 2011; Nowak 2012). I have attempted to explore the imperative, grounded in complexity theory, for abandoning applied social science that tests specific parsimonious theories in favor of applying meta-theories, theories about how to organize multiple theories, and meta-strategies, strategies about how to sequence many strategies.

While minimally sufficient deterrence is based on what we know about deterrence and defiance, that knowledge base has wide gaps of unknown knowables and unknowables that are complex or chaotic (Braithwaite and D'Costa 2018, chap. 12). The future gap-filling research agenda can be framed under the seven policy principles of minimally sufficient deterrence:

1. Escalate enforcement. Display intent to progressively escalate a responsive enforcement pyramid that involves progressive escalation of sanctions for wrongdoing and support for social responsibility.

This has been the heartland research priority of Valerie Braithwaite's and my research group since 1980 (e.g., see more than a hundred empirical evaluations of the application of responsive regulation to tax compliance by the Centre for Tax System Integrity: http://ctsi.org.au/; more broadly, see http://johnbraithwaite.com/responsive-regulation/).

2. Inexorability. Pursue inexorable consistency of detection of predatory crime. Communicate inexorable community commitment to stick with social support for those struggling with problems of lawbreaking until the problems are fixed.

Critical research contributions here bring together the established agenda of measuring the effects of perceived certainty of detection with perceptions that my supporters will deliver me unconditional support, 
sticking with my problems until they are fixed. While increasing consistency of detection will increase deterrence, having police be everywhere at all times risks undermining legitimacy, motivating defiance. Lawrence Sherman has coined the idea of a sweet spot of intensity of just enough deterrence through police presence at hot spots. Gibson, Slothower, and Sherman (2017) found such an optimal sweet spot of minimally sufficient patrol in Merseyside, UK. Though it is well established that intensive patrol at hot spots can reduce crime (Braga, Papachristos, and Hureau 2014), Gibson and her colleagues are the first to explore the possibility of reducing the intensity of hot-spot patrol without increasing crime, perhaps even reducing it somewhat through optimizing that sweet spot. This work opens a path to understanding cost-effective, minimally sufficient patrol.

3. Escalate social support. With repeated offending, increase social support. Even when there is escalation to a last resort of severe incapacitation, escalate social support further. Keep escalating social support until desistance is consolidated.

Perhaps the most critical research needed here is macrosociological and macroeconomic work on strategies for sustaining a more credible welfare state. It may be feasible to be politically effective in struggling for return to improving the condition of the welfare state.

4. Sharpen the Sword of Damocles. Cultivate the perception that "Trouble hangs inexorably over my head; they want to support me to avert it."

Here the "less prison" research agenda shows the kind of work that illuminates Sword of Damocles possibilities (Sherman 2011). This is illustrated through Slothower et al.'s (2017) West Midlands Police experiment, Offender Management by Turning Point (Deferred Prosecution with a Plan). Random assignment to deferred prosecution combined with social support substantially reduced crime harm, reduced the cost of the justice system, and increased victim satisfaction with outcomes, when compared with prosecuted cases.

5. Dynamic concentration of deterrence. Focus deterrence on lines that should never be crossed after an announcement date. Then 
progressively lift that line, raising our expectations of socially responsible citizens.

Research in this tradition led by David Kennedy and Mark Kleiman has not been linked to evidence-based learning on restorative justice and responsive business regulation, nor to dynamic concentration experience of international peacekeepers regulating war zones and negotiating gang surrenders into peace zones. A more interdisciplinary research imagination is required to see the complex of strategies, including escalated social support and reconciliation, within which to embed dynamic concentration of deterrence to increase its effectiveness. Future research must distinguish static focused deterrence effects from dynamic concentration effects.

6. Community engagement. Engage the community with offenders in widening restorative conversations that educate in the shamefulness of criminal predation for the many who participate in the conversations. Avert stigmatization.

The research required here includes the intersection of work on community engagement with crime control (e.g., Sampson, Raudenbush, and Earls 1997; Pratt and Cullen 2005; Odgers et al. 2009) and research on the Connectedness, Hope, Identity, Meaning, and Empowerment (CHIME) conclusion by Leamy et al. (2011) in their review of the "recovery capital" research tradition (Best 2017). The CHIME conclusion is that connectedness, hope, identity, meaning, and empowerment are needed for capacity for recovery from problems such as drug addiction, alcoholism, suicide attempts, and arrests. It is important to integrate the best psychological and criminological research on pride and shame dynamics and on shame acknowledgment as offenders renarrate their lives (Leach and Cidam 2015; Spruit et al. 2016).

7. Modesty. Settle for the modest general deterrence delivered by this shamefulness and a minimal number of cases that escalate toward the peak of the enforcement pyramid.

This is the "decrementalist" research strategy recommended by Braithwaite and Pettit (1990) on republican theory and criminal justice. It means evaluation research on how low imprisonment can go without crime be- 
ginning to increase. When we have no choice but to lock up extremely dangerous people, we can be justifiably pessimistic that this will deter those specific people when released. Yet others seeing that imprisonment does sometimes happen may deliver a modest quantum of general deterrence of the rest of the population. Braithwaite and Pettit's (1990) decrementalist research agenda went nowhere in the 28 years since it was proposed. No countries have pursued progressive reductions of imprisonment rates until empirical evidence emerged that serious crime problems were the result. This is a measure of how wide the gap is in every country between minimally sufficient deterrence and criminal justice policy.

\section{REFERENCES}

Ahmed, Eliza, and John Braithwaite. 2011. "Shame, Pride and Workplace Bullying." In Emotions, Crime and fustice, edited by Susanne Karstedt, Ian Loader, and Heather Strang. Oxford: Hart.

Ahmed, Eliza, Nathan Harris, John Braithwaite, and Valerie Braithwaite. 2001. Shame Management through Reintegration. Cambridge: Cambridge University Press.

Andenaes, Johannes. 1974. Punishment and Deterrence. Ann Arbor: University of Michigan Press.

Andrews, Donald A., and James Bonta. 1998. The Psychology of Criminal Conduct. 2nd ed. Cincinnati: Anderson. 2010. "Rehabilitating Criminal Justice Policy and Practice." Psycholoov, Public Policv, and Law 16(1):39-55.

Axelrod, Robert M. 1984. The Evolution of Cooperation. New York: Basic Books. Ayres, Ian, and John Braithwaite. 1992. Responsive Regulation: Transcending the Deregulation Debate. New York: Oxford University Press.

Barnes, Geoffrey C., Jordan M. Hyatt, Caroline M. Angel, Heather Strang, and Lawrence W. Sherman. 2015. "Are Restorative Justice Conferences More Fair than Criminal Courts? Comparing Levels of Observed Procedural Justice in the Reintegrative Shaming Experiments (RISE)." Criminal 7ustice Policv Review 26(2):103-30.

Becker, Gary S. 1993. "Nobel Lecture: The Economic Way of Looking at Behavior." Fournal of Political Economy 101(3):385-409.

Berger, Ulrich. 2011. "Learning to Cooperate via Indirect Reciprocity." Games and Economic Behavior 72(1):30-37.

Best, David. 2017. "Developing Strengths-Based Recovery Systems through Community Connections." Addiction 112(5):759-61. 
Black, Julia, and Robert Baldwin. 2010. "Really Responsive Risk-Based Regulation." Law and Policy 32(2):181-213.

Blumstein, Alfred. 2011. "Approaches to Reducing Both Imprisonment and Crime." Criminolooy and Public Policy 10(1):93-102.

Bouffard, Jeff, Maisha Cooper, and Kathleen Bergseth. 2017. "The Effectiveness of Various Restorative Justice Interventions on Recidivism Outcomes among Juvenile Offenders." Youth Violence and 7uvenile 7ustice 15(4):465-80.

Braga, Anthony A. 2002. Problem-Oriented Policing and Crime Prevention. Monsey, NY: Criminal Justice Press.

Braga, Anthony A., Robert Apel, and Brandon C. Welsh. 2013. "The Spillover Effects of Focused Deterrence on Gang Violence." Evaluation Review 37(34):314-42.

Braga, Anthony A., Andrew V. Papachristos, and David M. Hureau. 2014. "The Effects of Hot Spots Policing on Crime: An Updated Systematic Review and Meta-Analysis." Zustice Ouarterly 31(4):633-63.

Braga, Anthony A., and David L. Weisburd. 2012. "The Effects of Focused Deterrence Strategies on Crime: A Systematic Review and Meta-Analysis of the Empirical Evidence." Zournal of Research in Crime and Delinauency 49(3):323-58.

. 2014. "Must We Settle for Less Rigorous Evaluations in Large AreaBased Crime Prevention Programs? Lessons from a Campbell Review of Focused Deterrence." Zournal of Experimental Criminology 10(4):573-97.

Braithwaite, John. 1989. Crime, Shame, and Reintegration. Cambridge: Cambridge University Press.

_. 1995. "Inequality and Republican Criminology." In Crime and Inequality, edited by John Hagan and Ruth D. Peterson. Palo Alto, CA: Stanford University Press.

—. 1998. "Institutionalizing Distrust, Enculturating Trust." In Trust and Governance, edited by Valerie Braithwaite and Margaret Levi. New York: Russell Sage Foundation.

2001. "Youth Development Circles." Oxford Review of Education 27 (2):239-52.

. 2002. Restorative Fustice and Responsive Regulation. New York and Sydney: Oxford University Press and Federation Press.

. 2003. "Principles of Restorative Justice." In Restorative fustice and Criminal fustice: Competing or Reconcilable Paradigms? edited by Andrew von Hirsch, Julian V. Roberts, Anthony Bottoms, Kent Roach, and Mara Schiff. Oxford: Hart.

2005. Markets in Vice, Markets in Virtue. Sydney and New York: Federation Press and Oxford University Press.

. 2008. Regulatory Capitalism: How It Works, Ideas for Making It Work Better. Cheltenham, UK: Elgar.

. 2011. "The Essence of Responsive Regulation." University of British Columbia Law Review 44:475-520.

_. 2012. "Cascades of Violence and a Global Criminology of Place." Australian and New Zealand Fournal of Criminology 45:299-315. 
2016. "Restorative Justice and Responsive Regulation: The Question of Evidence.” RegNet Working Paper no. 51. Canberra: Australian National University, School of Regulation and Global Governance.

Braithwaite, John, Eliza Ahmed, and Valerie Braithwaite. 2006. "Shame, Restorative Justice and Crime." In Taking Stock: The Status of Criminological Theory, edited by Francis T. Cullen, John Paul Wright, and Kristie R. Blevins. New Brunswick, NJ: Transaction.

Braithwaite, John, and Bina D'Costa. 2018. Cascades of Violence. Canberra: ANU Press.

Braithwaite, John, and Peter Drahos. 2000. Global Business Regulation. Cambridge: Cambridge University Press.

Braithwaite, John, and Ali Gohar. 2014. "Restorative Justice, Policing, and Insurgency: Learning from Pakistan." Law and Society Review 48(3):531-61.

Braithwaite, John, and Seung-Hun Hong. 2015. "The Iteration Deficit in Responsive Regulation: Are Regulatory Ambassadors an Answer?" Reoulation and Governance 9(1):16-29.

Braithwaite, John, and Toni Makkai. 1994. "Trust and Compliance." Policing and Societs 4(1):1-12.

Braithwaite, John, Toni Makkai, and Valerie Braithwaite. 2007. Regulating Aged Care: Ritualism and the New Pyramid. Cheltenham, UK: Elgar.

Braithwaite, John, and Philip Pettit. 1990. Not fust Deserts: A Theory of Criminal Fustice. Oxford: Oxford University Press.

Brehm, Sharon S., and Jack W. Brehm. 1981. Psychological Reactance: A Theory of Freedom and Control. New York: Academic Press.

Broadhurst, Roderic, Thierry Bouhours, and Brigitte Bouhours. 2015. Violence and the Civilising Process in Cambodia. Cambridge: Cambridge University Press.

_. 2018. "Violence and Elias's Historical Sociology: The Case of Cambodia." British Fournal of Criminology, forthcoming.

Call, Charles T. 2012. Why Peace Fails: The Causes and Prevention of Civil War Recurrence. Washington, DC: Georgetown University Press.

Cerasoli, Christopher P., Jessica M. Nicklin, and Michael T. Ford. 2014. "Intrinsic Motivation and Extrinsic Incentives Jointly Predict Performance: A 40-Year Meta-Analysis.” Psycholooical Bulletin 140(4):980-1008.

Chalfin, Aaron, and Justin McCrary. 2017. "Criminal Deterrence: A Review of the Literature." Fournal of Economic Literature 55(1):5-48.

Cicero, Marcus Tullius. 1877. Tusculan Disputations. Translated by C. D. Yonge. New York: Harper \& Brothers.

Clark, Phil. 2010. The Gacaca Courts, Post-genocide fustice and Reconciliation in Rwanda: Fustice without Lawyers. Cambridge: Cambridge University Press.

Cullen, Francis T. 1994. "Social Support as an Organizing Concept for Criminology." Zustice Ouarterly 11(4):527-59.

Dancy, Geoff, Bridget Marchesi, Tricia Olsen, Leigh Payne, Andrew Reiter, and Kathryn Sikkink. 2013. "Stopping State Agents of Violence or Promoting Political Compromise? The Powerful Role of Transitional Justice Mechanisms." Paper presented at the American Political Science Association annual meeting, Chicago. 
Dekker, Sidney W. A., and Hugh Breakey. 2016. "'Just Culture': Improving Safety by Achieving Substantive, Procedural and Restorative Justice." Safetv Science 85:187-93.

Doob, Anthony, and Julian V. Roberts. 1983. Sentencing: An Analysis of the Public's View of Sentencing. Ottawa: Department of Justice, Canada. 1988. "Public Attitudes towards Sentencing in Canada." In Public Attitudes to Sentencing, edited by Nigel Walker and Mike Hough. Aldershot, UK: Gower.

Dorf, Michael C., and Charles F. Sabel. 1998. "A Constitution of Democratic Experimentalism.” Columbia Law Review 98(2):267-473.

Doyle, Michael W., and Nicholas Sambanis. 2006. Making War and Building Peace: United Nations Peace Operations. Princeton, NJ: Princeton University Press.

Dunford, Franklin W. 1990. "System-Initiated Warrants for Suspects of Misdemeanor Domestic Assault: A Pilot Study.” Zustice Quarterly 7(4):631-53.

Duriez, Stephanie A., Francis T. Cullen, and Sarah M. Manchak. 2014. "Is Project HOPE Creating a False Sense of Hope: A Case Study in Correctional Popularity." Federal Probation 78:57-70.

Durlauf, Steven N., and Daniel S. Nagin. 2011. "Overview of 'Imprisonment and Crime: Can Both Be Reduced?" Criminolooy and Public Policy 10(1):912.

Eckstein, Harry. 1975. "Case Study and Theory in Political Science." In Handbook of Political Science, vol. 7, edited by Fred I. Greenstein and Nelson W. Polsby. Reading, MA: Addison-Wesley.

Eisinger, Jesse. 2017. The Chickenshit Club: Why the Fustice Department Fails to Prosecute Executives. New York: Simon \& Schuster.

Eisner, Manuel. 2003. "Long-Term Historical Trends in Violent Crime." In Crime and 7ustice: A Review of Research, vol. 30, edited by Michael Tonry. Chicago: University of Chicago Press.

Elias, Norbert. 1978. The Civilizing Process. 2 vols. Oxford: Oxford University Press.

Feeley, Malcolm M. 1979. The Process Is the Punishment: Handling Cases in a Lower Criminal Court. New York: Sage.

Fortna, Virginia Page. 2008. Does Peacekeeping Work: Shaping Belligerents' Choices after Civil War. Princeton, NJ: Princeton University Press.

Frey, Bruno. 2017. "Policy Consequences of Pay-for-Performance and CrowdingOut." Fournal of Behavioral Economics for Policy 1(1):55-59.

Friesen, Lana. 2012. "Certainty of Punishment versus Severity of Punishment: An Experimental Investigation.” Southern Economic 7ournal 79(2):399-421.

Gangl, Katharina, Eva Hofmann, and Erich Kirchler. 2015. "Tax Authorities' Interaction with Taxpayers: A Conception of Compliance in Social Dilemmas by Power and Trust." New Ideas in Psychology 37:13-23.

Gibson, Christopher, Molly Slothower, and Lawrence W. Sherman. 2017. "A Cost-Effectiveness Comparison of Two Patrol Strategies.” Cambridoe Zournal of Evidence-Based Policing 1(4):225-43.

Gunningham, Neil, Peter Grabosky, and Darren Sinclair. 1998. Smart Regulation. Oxford: Oxford University Press. 
Haas, Nicole E., Maarten Van Craen, Wesley G. Skogan, and Diego M. Fleitas. 2015. "Explaining Officer Compliance: The Importance of Procedural Justice and Trust inside a Police Organization." Criminology and Criminal 7ustice 15 (4):442-63.

Harris, Nathan. 2001. "Shaming and Shame: Regulating Drink-Driving." In Shame Management through Reintegration, edited by Eliza Ahmed, Nathan Harris, John Braithwaite, and Valerie Braithwaite. Cambridge: Cambridge University Press.

- 2017. "Shame in Regulatory Settings." In Regulatory Theory: Foundations and Applications, edited by Peter Drahos. Canberra: ANU Press.

Hawken, Angela, and Mark Kleiman. 2009. Managing Drug Involved Probationers with Swift and Certain Sanctions: Evaluating Hawaii's HOPE. Washington, DC: National Institute of Justice.

Johnstone, Gerry. 2013. Restorative fustice: Ideas, Values, Debates. London: Routledge. Kennedy, David M. 2009. Deterrence and Crime Prevention: Reconsidering the Prospect of Sanction. New York: Routledge.

Kennedy, David M., Mark A. R. Kleiman, and Anthony A. Braga. 2017. "Beyond Deterrence." In Handbook of Crime Prevention and Community Safety, 2nd ed., edited by Nick Tilley and Aiden Sidebottom. London: Routledge.

Kinsey, Karyl A. 1986. "Theories and Models of Tax Cheating." Criminal fustice Abstracts 18:402-20.

Kleiman, Mark. 2009. When Brute Force Fails: How to Have Less Crime and Less Punishment. Princeton, NJ: Princeton University Press.

Klusemann, Stefan. 2012. "Massacres as Process: A Micro-sociological Theory of Internal Patterns of Mass Atrocities." European 7ournal of Criminology 9 (5):468-80.

Kuttippurath, Jayanarayanan, and Prijitha J. Nair. 2017. "The Signs of Antarctic Ozone Hole Recovery.” Scientific Reports 7(1). DOI:10.1038/s41598-01700722-7.

Lacey, Nicola. 2008. The Prisoners' Dilemma: Political Economy and Punishment in Contemporary Democracies. Cambridge: Cambridge University Press.

Latimer, Jeff, Craig Dowden, and Danielle Muise. 2001. The Effectiveness of Restorative fustice Practices: A Meta-Analysis. Ottawa: Department of Justice, Canada.

Lattimore, Pamela K., Doris Layton MacKenzie, Gary Zajac, Debbie Dawes, Elaine Arsenault, and Stephen Tueller. 2016. "Outcome Findings from the HOPE Demonstration Field Experiment." Criminology and Public Policy 15 (4):1103-41.

Leach, Colin Wayne, and Atilla Cidam. 2015. "When Is Shame Linked to Constructive Approach Orientation? A Meta-Analysis." Zournal of Personality and Social Psychology 109(6):983-1002.

Leamy, Mary, Victoria Bird, Clair Le Boutillier, Julie Williams, and Mike Slade. 2011. "Conceptual Framework for Personal Recovery in Mental Health: Systematic Review and Narrative Synthesis." British Fournal of Psychiatry 199 (6):445-52. 
Lipsey, Mark W. 2009. "The Primary Factors That Characterize Effective Interventions with Juvenile Offenders: A Meta-Analytic Overview." Victims and Offenders 4(2):124-47.

Lipton, Douglas S., Robert Martinson, and Judith Wilks. 1975. The Effectiveness of Correctional Treatment: A Survey of Treatment Evaluation Studies. New York: Praeger.

Lundahl, Brad W., Chelsea Kunz, Cynthia Brownell, Derrik Tollefson, and Brian L. Burke. 2010. "A Meta-Analysis of Motivational Interviewing: Twenty-Five Years of Empirical Studies." Research on Social Work Practice 20(2):137-60.

MacKenzie, Doris L., and David P. Farrington. 2015. "Preventing Future Offending of Delinquents and Offenders: What Have We Learned from Experiments and Meta-Analyses?" Zournal of Experimental Criminoloov 11(4):565-95.

Makkai, Toni, and John Braithwaite. 1994. "Reintegrative Shaming and Compliance with Regulatory Standards.” Criminology 32(3):361-85.

Manchak, Sarah M., and Francis T. Cullen. 2015. "Intervening Effectively with Juvenile Offenders: Answers from Meta-Analysis." In The Development of Criminal and Antisocial Behavior, edited by Julien Morizot and Lila Kazemian. New York: Springer.

Maruna, Shadd. 2001. Making Good: How Ex-Convicts Reform and Rebuild Their Lives. Washington, DC: American Psychological Association.

Maxwell, Gabrielle, and Allison Morris. 2002. "The Role of Shame, Guilt, and Remorse in Restorative Justice Processes for Young People." In Restorative fustice: Theoretical Foundations, edited by Elmar G. M. Weitekamp and Hans-Jürgen Kerner. Cullompton, Devon, UK: Willan.

Mazzolini, Gabriele, Laura Pagani, and Alessandro Santoro. 2017. "The Deterrence Effect of Real-World Operational Tax Audits." Working Paper no. 359. Milan: University of Milan Bicocca, Department of Economics, Management, and Statistics. Available at Social Science Research Network.

Mendoza, Juan P., Jacco L. Wielhouwer, and Erich Kirchler. 2017. "The Backfiring Effect of Auditing on Tax Compliance." Zournal of Economic Psychology 62:284-94.

Miller, Susan L., and M. Kristen Hefner. 2015. "Procedural Justice for Victims and Offenders? Exploring Restorative Justice Processes in Australia and the US." Fustice Ouarterly 32(1):142-67.

Nagin, Daniel S. 2013. "Deterrence in the Twenty-First Century." In Crime and Fustice in America, 1975-2025, edited by Michael Tonry. Vol. 42 of Crime and 7ustice: A Review of Research, edited by Michael Tonry. Chicago: University of Chicago Press.

Nagin, Daniel S., Francis T. Cullen, and Cheryl Lero Jonson. 2009. "Imprisonment and Reoffending." In Crime and 7ustice: A Review of Research, vol. 38, edited by Michael Tonry. Chicago: University of Chicago Press.

Nagin, Daniel S., Robert M. Solow, and Cynthia Lum. 2015. "Deterrence, Criminal Opportunities, and Police." Criminology 53(1):74-100.

Nowak, Martin A. 2012. "Evolving Cooperation." Zournal of Theoretical Biolooy 299:1-8. 
Odgers, Candice L., Terrie E. Moffitt, Laura M. Tach, Robert J. Sampson, Alan Taylor, Charlotte L. Matthews, and Avshalom Caspi. 2009. "The Protective Effects of Neighborhood Collective Efficacy on British Children Growing Up in Deprivation: A Developmental Analysis." Developmental Psycholooy 45 (4):942-57.

Olsen, Tricia D., Leigh A. Payne, and Andrew Reiter. 2010. Transitional fustice in the Balance: Comparing Processes, Weighing Efficacy. Washington, DC: US Institute of Peace.

Osterloh, Margit, and Buno S. Frey. 2013. "Motivation Governance." In Handbook of Economic Organization, edited by Anna Grandori. Cheltenham, UK: Elgar.

Parker, Christine. 2004. "Restorative Justice in Business Regulation? The Australian Competition and Consumer Commission's Use of Enforceable Undertakings." Modern Law Review 67(2):209-46.

Paternoster, Raymond, and Sally Simpson. 1996. "Sanction Threats and Appeals to Morality: Testing a Rational Choice Model of Corporate Crime." Law and Societv Review 30(3):549-83.

Patterson, Gerald R., and Lew Bank. 1989. "Some Amplifying Mechanisms for Pathologic Processes in Families." In Systems and Development: The Minnesota Symposia on Child Psychology. Hillsdale, NJ: Erlbaum.

Pennell, Joan, and Gale Burford. 2000. "Family Group Decision Making: Protecting Children and Women." Child Welfare 79(2):131-58.

Pettit, Philip. 1997. Republicanism. Oxford: Oxford University Press.

Pinker, Jonathan. 2011. The Better Angels of Our Nature. New York: Penguin.

Pontell, Henry N. 1978. "Deterrence: Theory versus Practice." Criminology 16 (1):3-22.

Pontell, Henry N., William K. Black, and Gilbert Geis. 2014. "Too Big to Fail, Too Powerful to Ail? On the Absence of Criminal Prosecutions after the 2008 Financial Meltdown." Crime, Law, and Social Change 61(1):1-13.

Pratt, Travis C., and Francis T. Cullen. 2005. "Assessing Macro-Level Predictors and Theories of Crime: A Meta-Analysis." In Crime and 7ustice: A Review of Research, vol. 32, edited by Michael Tonry. Chicago: University of Chicago Press.

Pratt, Travis C., and Jillian J. Turanovic. 2018. "Celerity and Deterrence." In Deterrence, Choice, and Crime: Contemporary Perspectives, edited by Daniel S. Nagin, Francis T. Cullen, and Cheryl Lero Jonson. New York: Routledge, forthcoming.

Rains, Stephen A. 2013. "The Nature of Psychological Reactance Revisited: A Meta-Analytic Review." Human Communication Research 39(1):47-73.

Robinson, Laurie O. 2011. "Exploring Certainty and Severity." Criminology and Public Policy 10(1):85-92.

Rubak, Sune, Annelli Sandbæk, Torsten Lauritzen, and Bo Christensen. 2005. "Motivational Interviewing: A Systematic Review and Meta-Analysis." British Journal of General Practice 5(513):305-12.

Rubin, Michael. 2014. Dancing with the Devil: The Perils of Engaging Rogue Regimes. New York: Encounter. 
Sampson, Robert J., Stephen W. Raudenbush, and Felton Earls. 1997. "Neighborhoods and Violent Crime: A Multilevel Study of Collective Efficacy." Science 277(5328):918-24.

Schell-Busey, Natalie, Sally S. Simpson, Melissa Rorie, and Mariel Alper. 2016. "What Works? A Systematic Review of Corporate Crime Deterrence." Criminology and Public Policy 15(2):387-416.

Schiff, Mara F. 1999. "The Impact of Restorative Interventions on Juvenile Offenders." In Restorative fuvenile fustice, edited by Lode Walgrave and Gordon Bazemore. Monsey, NY: Criminal Justice Press.

Sherman, Lawrence W. 1992. Policing Domestic Violence. New York: Free Press. . 2011. "Offender Desistance Policing: Less Prison and More Evidence of Rehabilitating Offenders." In Antisocial Behavior and Crime: Contributions of Developmental and Evaluation Research to Prevention and Intervention, edited by Thomas Bliesener, Andreas Beelmann, and Mark Stemmler. Cambridge, MA: Hogrefe.

- 2014. "Experiments in Criminal Sanctions: Labeling, Defiance, and Restorative Justice." In Labeling Theory: Empirical Tests, edited by David P. Farrington and Joseph Murray. New Brunswick, NJ: Transaction.

Sherman, Lawrence W., and Heather Strang. 1997. "Restorative Justice and Deterring Crime.” RISE Working Paper no. 4. Canberra: Australian National University, Law Program, Research School of Social Sciences.

Sherman, Lawrence W., Heather Strang, Gregory C. Barnes, John Braithwaite, Nova Inkpen, and M. M. Teh. 1998. Experiments in Restorative Policing: A Progress Report. Canberra: Australian National University, Law Program, Research School of Social Sciences.

Sikkink, Kathryn. 2011. The Justice Cascade: How Human Rights Prosecutions Are Changing World Politics. New York: Norton.

Slothower, Molly, Peter Neyroud, Jamie Hobday, Lawrence Sherman, Barak Ariel, Eleanor Neyroud, and Geoffrey Barnes. 2017. The Turning Point Project 2-Year Outcomes. Report to Chief Officers. Birmingham, UK: West Midlands Police.

Sparrow, Malcolm K. 2000. The Regulatory Craft. Washington, DC: Brookings Institution.

Spruit, Anouk, Frans Schalkwijk, Eveline Van Vugt, and Geert Jan Stams. 2016. "The Relation between Self-Conscious Emotions and Delinquency: A MetaAnalysis." Agoression and Violent Behavior 28:12-20.

Stanard, Rebecca Powell. 1999. "The Effect of Training in a Strengths Model of Case Management on Client Outcomes in a Community Mental Health Center." Community Mental Health Fournal 35(2):169-79.

Strang, Heather, Lawrence W. Sherman, Evan Mayo-Wilson, Daniel Woods, and Ariel Barak. 2013. Restorative fustice Conferencing (R7C) Using Face-to-Face Meetings of Offenders and Victims: Effects on Offender Recidivism and Victim Satisfaction; a Systematic Review. Oslo: Campbell Collaboration.

Sutherland, Edwin. 1983. White-Collar Crime: The Uncut Version. New Haven, CT: Yale University Press. (Originally published 1949.)

Toft, Monica Duffy. 2010. Securing the Peace: The Durable Settlement of Civil Wars. Princeton, NJ: Princeton University Press. 
Tonry, Michael. 2018. “An Honest Politician's Guide to Deterrence.” In Deterrence, Choice, and Crime: Contemporary Perspectives, edited by Daniel S. Nagin, Francis T. Cullen, and Cheryl Lero Jonson. New York: Routledge, forthcoming.

Travis, Jeremy, Bruce Western, and F. Stevens Redburn, eds. 2014. The Growth of Incarceration in the United States: Exploring Causes and Consequences. Washington, DC: National Academies Press.

Tyler, Tom R. 1990. Why People Obey the Law. New Haven, CT: Yale University Press.

Tyler, Tom R., and Yuen J. Huo. 2002. Trust in the Law: Encouraging Public Cooperation with the Police and Courts. New York: Russell Sage Foundation.

Tyler, Tom R., Lawrence Sherman, Heather Strang, Geoffrey C. Barnes, and Daniel Woods. 2007. "Reintegrative Shaming, Procedural Justice, and Recidivism: The Engagement of Offenders' Psychological Mechanisms in the Canberra RISE Drinking-and-Driving Experiment." Law and Societv Review 41(3):553-86.

Umbreit, Mark, and Robert Coates. 1992. Victim-Offender Mediation: An Analysis of Programs in Four States of the US. Minneapolis: Citizens Council Mediation Services.

Weisburd, David, David P. Farrington, and Charlotte Gill. 2017. "What Works in Crime Prevention and Rehabilitation." Criminology and Public Policy 16 (2):415-49.

Weisburd, David, Cody W. Telep, Joshua C. Hinkle, and John E. Eck. 2010. "Is Problem-Oriented Policing Effective in Reducing Crime and Disorder? Findings from a Campbell Systematic Review." Criminology and Public Policy 9(1):139-72.

Wilson, David B., Ajima Olaghere, and Catherine S. Kimbrell. 2017. Effectiveness of Restorative Fustice Principles in Fuvenile fustice: A Meta-Analysis. Washington, DC: US Department of Justice, Office of Juvenile Justice and Delinquency Prevention.

Wong, Jennifer S., Jessica Bouchard, Jason Gravel, Martin Bouchard, and Carlo Morselli. 2016. "Can At-Risk Youth Be Diverted from Crime? A MetaAnalysis of Restorative Diversion Programs." Criminal 7ustice and Behavior 43(10):1310-29.

Yeung, Karen. 2004. Securing Compliance. Oxford: Oxford University Press.

Zehr, Howard. 2015. The Little Book of Restorative Justice. New York: Skyhorse Publishing.

Zimring, Franklin E. 2011. The City That Became Safe: New York's Lessons for Urban Crime and Its Control. New York: Oxford University Press. 